\title{
Partial Oxidation for Improved Cold Starts in Alcohol-Fueled Engines: Phase II Topical Report
}

\author{
Arthur D. Little, Inc. \\ Cambridge, Massachusetts
}

NREL Technical Monitor: Peg Whalen

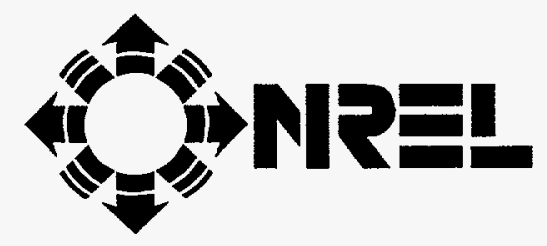

Alternative Fuels Hotline: 1-800-423-1DOE

Alternative Fuels Data Center World Wide Wéb Site: http://www.afdc.doe.gov

\author{
National Renewable Energy Laboratory \\ 1617 Cole Boulevard \\ Golden, Colorado 80401-3393 \\ A national laboratory of the \\ U.S. Department of Energy \\ Managed by the Midwest Research Institute \\ For the U.S. Department of Energy \\ Under Contract No. DE-AC36-83CH10093
}

Prepared under Subcontract Number YCC-5-14050-01

April 1998

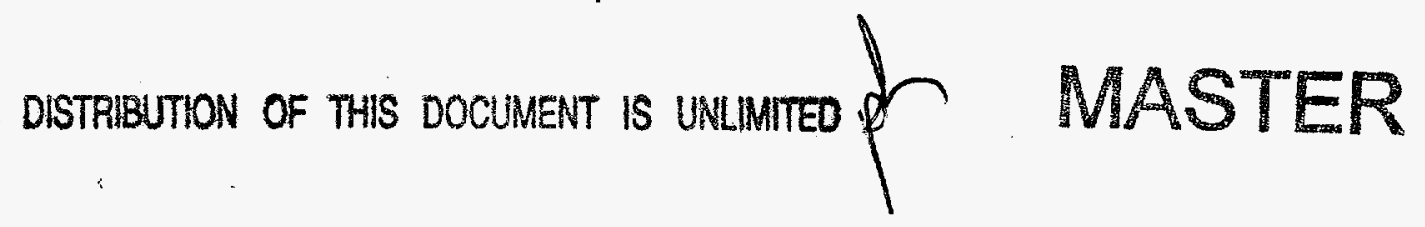




\section{NOTICE}

This report was prepared as an account of work sponsored by an agency of the United States government. Neither the United States government nor any agency thereof, nor any of their employees, makes any warranty, express or implied, or assumes any legal liability or responsibility for the accuracy, completeness, or usefulness of any information, apparatus, product, or process disclosed, or represents that its use would not infringe privately owned rights. Reference herein to any specific commercial product, process, or service by trade name, trademark, manufacturer, or otherwise does not necessarily constitute or imply its endorsement, recommendation, or favoring by the United States govemment or any agency thereof. The views and opinions of authors expressed herein do not necessarily state or reflect those of the United States government or any agency thereof.

Available to DOE and DOE contractors from:

Office of Scientific and Technical Information (OSTI)

P.O. Box 62

Oak Ridge, TN 37831

Prices available by calling (423) $576-8401$

Available to the public from:

National Technical Information Service (NTIS)

U.S. Department of Commerce

5285 Port Royal Road

Springfield, VA 22161

(703) $487-4650$ 


\section{DISCLAIMER}

Portions of this document may be illegible electronic image products. Images are produced from the best available original document. 


\section{Contents}

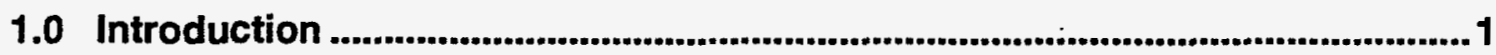

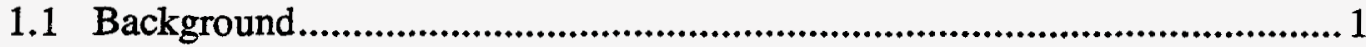

1.2 Summary of Phase I Development......................................................... 1

1.3 Objective of Phase II Development ..................................................... 3

2.0 Prototype Integrated Cold-start System ......................................................3

2.1 Design Development and System Modeling .............................................5

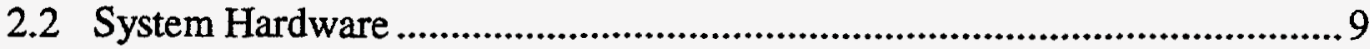

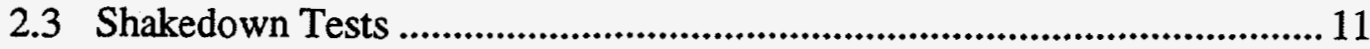

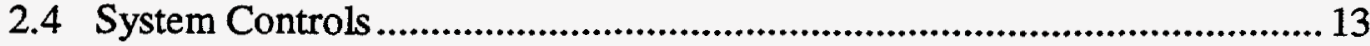

3.0 Prototype Cold-Start System Testing .............................................................15

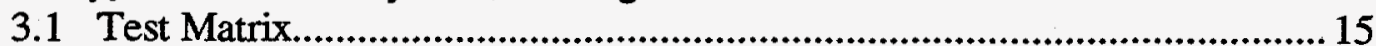

3.2 Test Series 1: Optimization of Fueling Strategy...................................... 15

3.3 Test Series 2: Cold Startability Improvement ..................................... 18

3.4 Test Series 3: Cold-Start Emissions Reduction ..................................... 18

4.0 System Design Update.............................................................................................222

4.1 Controls Updates and Their Impact on Cold-Start Performance ................. 22

4.2 Hardware Updates and Their Impact on Cold-Start Performance ............... 22

4.3 Impact on Compatibility and Commercialization..................................... 25

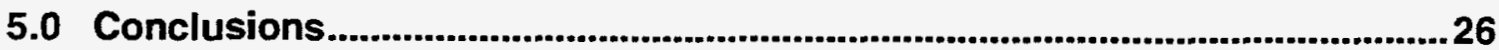

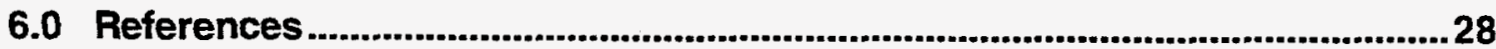

7.0 Appendix: Testing Facilities and Procedures .............................................29 


\section{Figures}

Figure 2-1: Schematic of Prototype Integrated Cold-Start System.............................. 4

Figure 2-2: Model for Minimum Flow (Cranking) Case....................................... 7

Figure 2-3: Model for Maximum Flow (Fast Idle) Case ........................................ 8

Figure 2-4: Integration of the Cold-Start System with the

1992 3.1L Chevrolet Lumina Flexible-Fuel Engine ................................9

Figure 2-5: Prototype Cold-Start POX Reactor Schematic ....................................... 10

Figure 2-6: Experimental Arrangement for Prototype Cold-Start Device Shakedown Tests........................................................................ 12

Figure 2-7: Logic Diagram of the Command States in the PC-Based Controller......... 16

Figure 3-1: Cold-Start Fueling Strategy Using Reformate Only at $-12^{\circ} \mathrm{C} \ldots \ldots \ldots \ldots \ldots \ldots . . . . . .17$

Figure 3-2: Cold Start at $-5^{\circ} \mathrm{C}$ Using the Prototype Integrated Cold-Start System ...... 19

Figure 3-3: Cold Start at $-18^{\circ} \mathrm{C}$ Using the Prototype Integrated Cold-Start System

Figure 3-4: Improvement in Engine Cold-Start Performance Obtained by Starting the Engine on Reformate from the Integrated Cold-Start System

Figure 3-5: On-Line Emission Measurements of Criteria Pollutants [(a) $\mathrm{HC}$,

(b) $\mathrm{CO}$, (c) $\mathrm{NO}_{\mathrm{x}}$ ] Generated from Starting the Engine with the

Baseline Fueling and the Integrated Cold-Start System.

Figure 4-1: Cold Start at $-10^{\circ} \mathrm{C}$ Using the Prototype Integrated Cold-Start System with a Transition to PFI E95

Figure 4-2: POX Chamber and Heat Exchanger Exit Temperatures during a

Cold Start at $-12^{\circ} \mathrm{C}$ Using the Prototype Integrated Cold-Start

System .25

Figure 4-3: Standard Automotive Components Used by the Prototype Integrated Cold-Start System. 


\section{Tables}

Table 1-1: Simulated POX Product Composition Used in Phase I Tests........................ 2

Table 2-1: System Model Variables ..........................................................................5

Table 2-2: Signals Monitored by the PC-Based Controller/DAQ .............................. 14

Table 3-1: Integrated Cold-Start System Test Matrix ........................................ 15

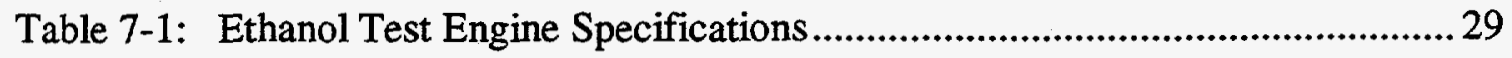

Table 7-2: Environmental Test Chamber Specifications......................................... 30 


\subsection{Introduction}

\subsection{Background}

Alcohol fuels have demonstrated the potential to improve air quality relative to petroleum-derived fuels by reducing vehicle tail-pipe emissions. These liquid fuels are emerging as the preferred alternative because they afford a superior range (compared to gaseous alternatives), and they can be derived from renewable resources. However, alcohol fuels exhibit poor cold-start performance because of their low volatility. Neat alcohol engines become difficult, if not impossible, to start at temperatures close to or below freezing. Improvements in the cold-start performance (both time to start and emissions) are essential to capture the full benefits of alcohols as an alternative transportation fuel.

The objective of this project was to develop a neat alcohol partial oxidation (POX) reforming technology to improve an alcohol engine's ability to start at low temperatures (as low as $-30^{\circ} \mathrm{C}$ ) and to reduce its cold-start emissions. The project emphasis was on fuel-grade ethanol (E95) but the technology can be easily extended to other alcohol fuels. Ultimately a compact, on-vehicle, ethanol POX reactor was developed as a fuel system component to produce a hydrogen-rich, fuel-gas mixture for cold starts.

The POX reactor is an easily controllable combustion device that allows flexibility during engine startup even in the most extreme conditions. It is a small device that is mounted directly onto the engine intake manifold. The gaseous fuel products (or reformate) from the POX reactor exit the chamber and enter the intake manifold, either replacing or supplementing the standard ethanol fuel consumed during an engine start. The combustion of the reformate during startup can reduce engine start time and tail-pipe emissions. This concept draws directly from developments made in ongoing U.S. Department of Energy (DOE)sponsored programs to develop POX reformers for mobile fuel cell applications $[1,2]$.

This project, entitled Partial Oxidation for Improved Cold Start in Alcohol Fueled Engines, was divided into two phases. The primary objective of Phase I was to demonstrate the feasibility of using ethanol POX to improve cold-start performance. The primary objective of Phase II was to develop a prototype coldstart POX system and demonstrate the cold-start performance of an integrated POX system on a light-duty vehicle engine. This topical report summarizes the efforts undertaken in Phase II. We have demonstrated significant improvements in the cold-start performance of an ethanol-fueled engine using a prototype integrated cold-start system.

\subsection{Summary of Phase I Development}

During Phase I a series of tests was conducted to demonstrate the feasibility of using ethanol POX to improve cold-start performance. An experimental test facility was developed in preparation for the concept validation experiments. The facility included the following specialized hardware: an ethanol-compatible test 
engine, an environmental test chamber to simulate cold ambient conditions, and a gas blending rig to simulate the products from a POX reactor.

The tests encompassed baseline testing of the E95-fueled engine; scoping tests to characterize the combustible range of POX products in-cylinder; cold-start tests on simulated POX products; and design, development, and bench testing of a prototype cold-start POX reactor.

Table 1-1 shows the POX products composition used for the bulk of the Phase I tests. This composition is representative of that resulting from the lowtemperature ethanol POX at an equivalence ratio of approximately 3.0.

Table 1-1: Simulated POX Product Composition Used in Phase I Tests

\begin{tabular}{|c|c|}
\hline \multirow{8}{*}{$\mathrm{A}_{1}$} & \\
\hline $\mathrm{H}_{2}$ & 14.5 \\
\hline $\mathrm{CO}$ & 19.7 \\
\hline $\mathrm{CO}_{2}$ & 3.8 \\
\hline $\mathrm{CH}_{4}$ & 3.9 \\
\hline $\mathrm{N}_{2}$ & 58.1 \\
\hline
\end{tabular}

Before all simulated POX testing, the engine's baseline performance on E95 was characterized over a wide range of intake temperatures. We determined that the engine begins to experience failed starts (i.e., more than 30 seconds of cranking) at approximately $0^{\circ} \mathrm{C}$. Initial simulated $\mathrm{POX}$ product modeling and testing indicated that typical ethanol reformate added to the intake air has a wide flammability range. This indicated that there could be wide flexibility in the engine cold-start fueling strategy using this technology.

With this information several cold-start fueling strategies were evaluated. The preferred strategy involved increasing the POX product flow rate to match the engine fueling requirement during cranking, start, and idle. Once idle was achieved, the port fuel-injected (PFI) E95 was activated and the POX product flow was reduced to zero. This fueling strategy became the preferred approach throughout the Phase I and ultimately the Phase II testing. Using this strategy, startability range was extended to $-30^{\circ} \mathrm{C}$ with starts around 5 seconds. At the same time we demonstrated that starting a cold engine (approximately $0^{\circ} \mathrm{C}$ ) on simulated POX products could reduce the time-averaged hydrocarbon ( $\mathrm{HC}$ ) and carbon monoxide (CO) emissions by a factor of 10 during the first 90 seconds after start of cranking.

Having validated the concept, efforts focused on the design and fabrication of a prototype POX reactor. Bench tests verified low-temperature ignitability, combustion stability, and fuel species production for the prototype reactor. The successful completion of Phase I prepared the way for Phase II developments of an integrated cold-start system. 


\subsection{Objective of Phase II Development}

The objective of Phase II was to develop specifications and a preliminary design for an integrated cold-start POX system. The system was to include the hardware and controls needed for complete vehicle integration with a light-duty alcoholfueled engine. Hardware flexibility to accommodate future optimization and compatibility with modern vehicle technology was the goal when designing, procuring, and fabricating the cold-start system. To keep the system simple and versatile, no modifications were made to the engine controls. Integrated "turn key" tests were conducted to evaluate the performance of the system and the coldstart performance of the engine with the system. Ultimately the objective was to demonstrate the feasibility and performance of an integrated cold-start POX system.

\subsection{Prototype Integrated Cold-Start System}

A schematic of the prototype integrated cold-start POX system appears in Figure 2-1. The test engine was a 1992 3.1L Chevrolet Lumina flexible-fuel vehicle engine, and the POX system is coupled to it between the throttle body (T1) and the intake manifold. Within the integrated system, air is required by both the engine to combust the fuel species and the POX reactor to reform the liquid E95. As the engine cranks, air will be drawn not only past $\mathrm{T} 1$ and into the cylinders, but also past the second throttle (T2) and into the POX reactor. Within the integrated system there are also multiple fuel delivery paths. The first delivers liquid E95 to the engine via port fuel injectors. The next delivers liquid E95 to the POX reactor for reforming. The last carries the reformate from the reactor to the intake manifold, where it is drawn in by the engine during the intake stroke. In general the POX-related hardware was controlled by a PC-based controller and the engine was controlled by the electronic control module (ECM). The details of the integrated system hardware and controls are presented in the subsequent sections. 


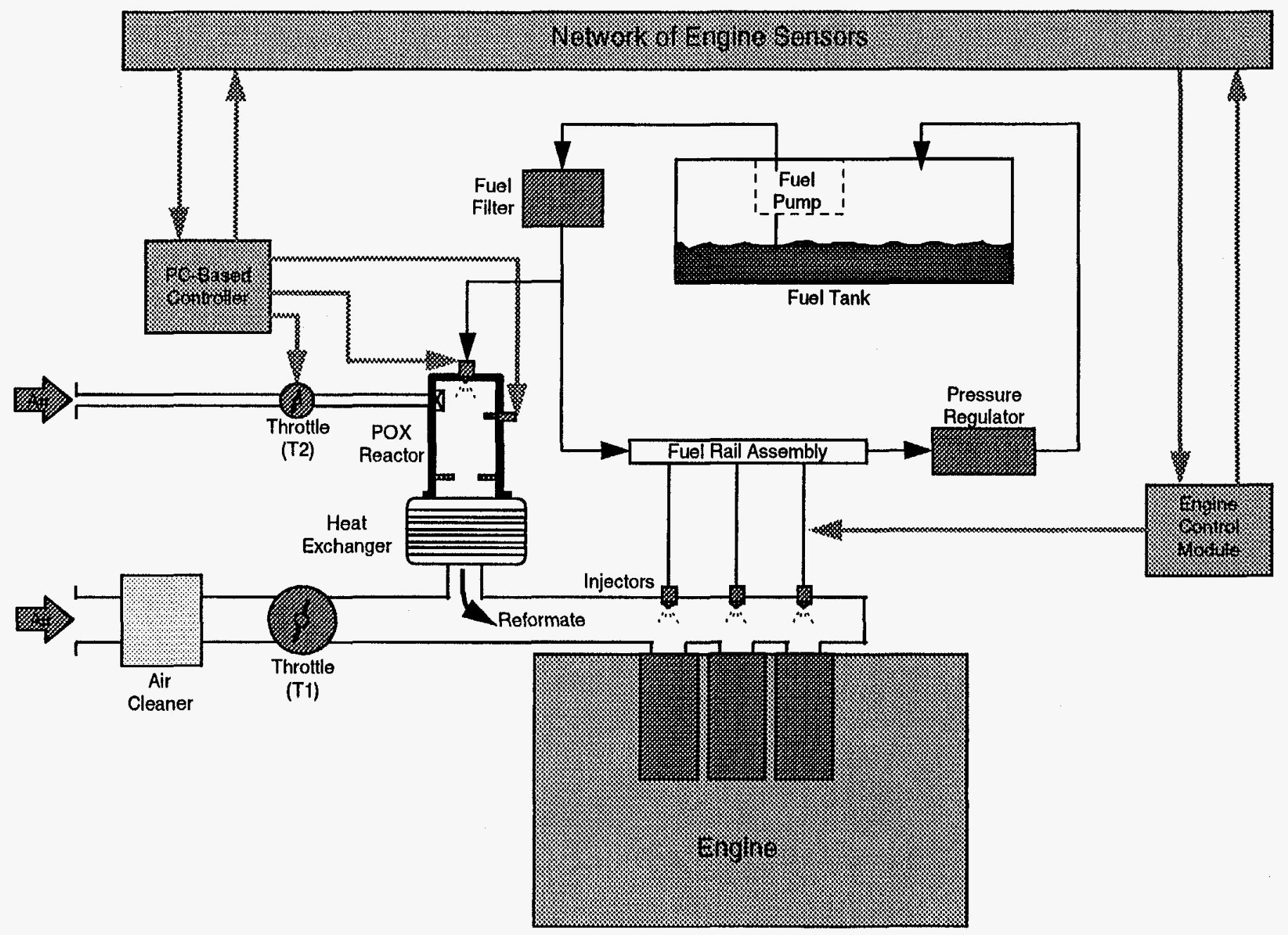

Figure 2-1: Schematic of Prototype Integrated Cold-Start System 


\subsection{Design Development and System Modeling}

A simple analytical model of the integrated cold-start system was created to help design the POX system. A series of bench-scale tests was then completed on the POX system to validate its performance once the required hardware was fabricated and assembled. Both efforts were vital before integration with the engine.

\subsubsection{Integrated System Analytical Model}

The model divides the system into three major parts: the POX reactor, the heat exchanger, and the engine. For each major section the model accepts inputs and computes outputs related to the physical state at that point in the system. This provided valuable hardware design and performance information while maintaining reactor and engine equivalence ratios $(\Phi)$ of 3 and 1, respectively. A list of the system component input and output variables for the model is given in Table 2-1.

Table 2-1: System Model Variables

\begin{tabular}{|c|c|c|c|c|}
\hline Model & Input & & Output & \\
\hline POX Reactor & $\begin{array}{l}\text { Fuel LHV } \\
\text { Fuel Stoichiometric F/A } \\
\text { Stoichiometry } \\
\text { Reformate Ratio of Specific Heats } \\
\text { Air Inlet Area } \\
\text { Outlet Area }\end{array}$ & $\begin{array}{l}\text { LHV } \\
\text { FAstc } \\
\text { PHipx } \\
\text { Kpx } \\
\text { Apx_in } \\
\text { Apx_out }\end{array}$ & $\begin{array}{l}\text { Fuel Flow Rate } \\
\text { Input Fuel Heat Rate } \\
\text { Reformate Temperature } \\
\text { Reformate Molecular Weight } \\
\text { Reformate Lower Heating Value } \\
\text { Inlet Air Density } \\
\text { Air Flow Rate } \\
\text { Inlet Air Velocity } \\
\text { Inlet Air Mach Number } \\
\text { Inlet Air Dynamic Head } \\
\text { Reformate Mass Flow Rate } \\
\text { Reformate Fuel Heat Rate } \\
\text { Reformate Specific Heat } \\
\text { Reformate Density } \\
\text { Reformate Volumetric Flow Rate } \\
\text { Reformate Outlet Velocity } \\
\text { Reformate Outlet Mach Number } \\
\text { Reformate Dynamic Head } \\
\text { Thermal Heat Release }\end{array}$ & $\begin{array}{l}\text { dFpx_in } \\
\text { Qpx_in } \\
\text { Tpx } \\
\text { MWpx } \\
\text { LHVpx } \\
\text { Dpx_in } \\
\text { dApx } \\
\text { Vpx_in } \\
\text { NMair } \\
\text { dyHpx_in } \\
\text { dMpx } \\
\text { dFpx_out } \\
\text { Cppx } \\
\text { Dpx_out } \\
\text { dVpx } \\
\text { Vpx_out } \\
\text { NMpx } \\
\text { dyHpx_out } \\
\text { Qpx }\end{array}$ \\
\hline $\begin{array}{l}\text { POX Heat } \\
\text { Exchanger }\end{array}$ & $\begin{array}{l}\text { Reformate Outlet Temperature } \\
\text { Outlet Area }\end{array}$ & $\begin{array}{l}\text { Thx_out } \\
\text { Ahx_out }\end{array}$ & $\begin{array}{l}\text { Reformate Average Specific Heat } \\
\text { Reformate Sensible Heat Change } \\
\text { Removed Heat } \\
\text { Outlet Velocity }\end{array}$ & $\begin{array}{l}\text { Cp_hx } \\
\text { Qsen } \\
\text { Qout } \\
\text { Vhx_out }\end{array}$ \\
\hline Engine & $\begin{array}{l}\text { Soak Temperature } \\
\text { Speed } \\
\text { Displacement } \\
\text { Volumetric Efficiency } \\
\text { Inlet Charge Temperature } \\
\text { Manifold Pressure } \\
\text { Stoichiometry } \\
\text { Engine Indicated Efficiency } \\
\text { New Inlet Charge, Soak Temp Weight }\end{array}$ & $\begin{array}{l}\text { Teng } \\
\text { RPM } \\
\text { CID } \\
\text { Evol } \\
\text { Tchg } \\
\text { Pman } \\
\text { PHleng } \\
\text { Eind } \\
\text { Ksoak }\end{array}$ & $\begin{array}{l}\text { Volumetric Flow Rate } \\
\text { Cylinder Charge Density } \\
\text { Charge Mass Flow Rate } \\
\text { Throttle Air Flow Rate } \\
\text { Mixed Charge Temperature } \\
\text { LHV Energy Rate } \\
\text { Indicated Power } \\
\text { Indicated Torque } \\
\text { Indicated MEP }\end{array}$ & $\begin{array}{l}\text { dVeng } \\
\text { Deylchg } \\
\text { dMeng } \\
\text { dAth } \\
\text { Tmix } \\
\text { IHPthm } \\
\text { IHPmc } \\
\text { Ind Torq } \\
\text { IMEP }\end{array}$ \\
\hline Ambient & $\begin{array}{l}\text { Pressure } \\
\text { Air Temperature }\end{array}$ & $\begin{array}{l}\text { Pamb } \\
\text { Tamb }\end{array}$ & & \\
\hline
\end{tabular}


The POX reactor model requires fuel property and flow area inputs to estimate the influence of reactor stoichiometry on system conditions. The model outputs the air, fuel, and reformate flow rates, in addition to the reformate temperature, heating value, specific heat, velocity, and the like. The reformate composition and lower heating value were calculated using a separate chemical kinetics model, and the results of this model were incorporated into a series of second order equations fit to the data over the stoichiometry range of interest $(2.5<\phi<4.5)$ for use in this model.

The heat exchanger model computes the outlet velocity and related flow parameters, which can then be reviewed for high values that suggest excessive pressure drop through the heat exchanger. Pressure drops are not calculated. The maximum allowable temperature for reformate entering the engine intake manifold is $95^{\circ} \mathrm{C}$. The model calculates how much heat must be removed by the heat exchanger to maintain this exit temperature.

The engine model couples the POX reactor to the engine requirements. Variables such as the POX reactor air flow and fuel flow are derived from the engine speed, displacement, volumetric efficiency, manifold air pressure, and temperature. In this way the POX reactor can be designed to satisfy the engine's fueling requirements during a cold start.

\subsubsection{Application of the Model}

The two engine operating conditions that were modeled at an ambient temperature of $-30^{\circ} \mathrm{C}$ include a cranking $(100 \mathrm{rpm})$ and a fast idling $(1,200 \mathrm{rpm})$ engine. These two conditions represent the most extreme cases the integrated cold-start system would face.

During cranking at low temperatures, the main issue was whether there was adequate air flow through the integrated system to operate the POX reactor and sustain combustion in-cylinder. Figure 2-2 represents the model inputs and outputs used to examine this minimum flow rate case. The input variables are shown in bold print. Experimental data from Phase I engine testing indicated that the inlet manifold pressure was 1 bar under these conditions. The model computed that for the reactor design the inlet air flow velocity (Vpx_in) was considerably lower than the desired tangential velocity for the reactor flow. (A significant tangential inlet velocity is required to promote the desired flow-field in the reactor and stabilize the very rich flame.) This suggested that a smaller inlet port area may be desired. Furthermore, the calculated indicated engine torque (assuming an engine indicated efficiency of $30 \%$ ) was about $15 \mathrm{~kg} \mathrm{~m}$. This torque is sufficient to overcome engine friction even at low operating temperatures and is sufficient to accelerate the engine from its initial cranking speed. 


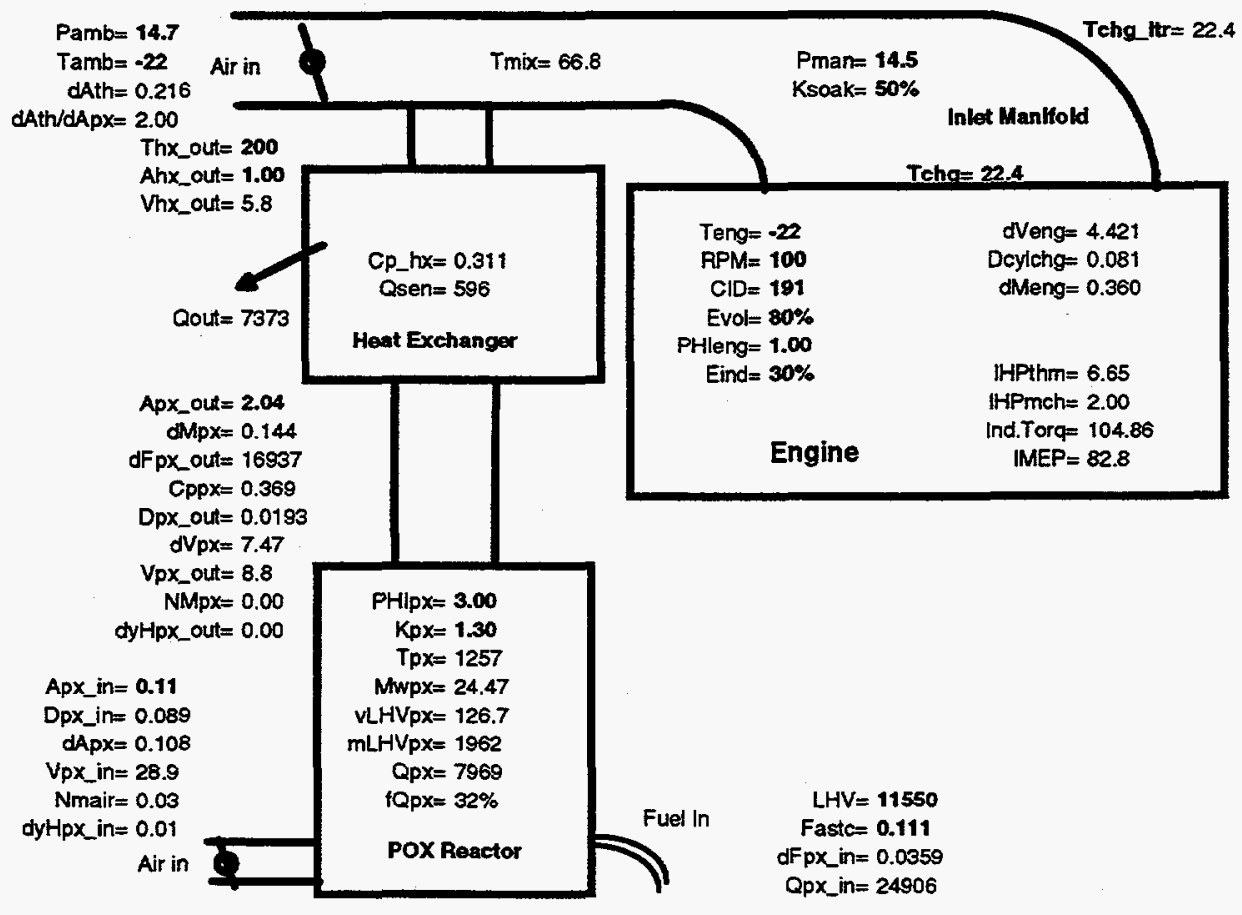

Figure 2-2: Model for Minimum Flow (Cranking) Case

The results of the other extreme condition, a fast idle at $-30^{\circ} \mathrm{C}$, appear in Figure 2-3. The input variables are shown in bold print. The main issue with this condition was whether the Phase I prototype POX reactor was large enough to satisfy the engine's steady-state idle fueling requirements with reformate only. Recall that the proposed fueling strategy starts and idles the engine on reformate only and then transitions to PFI E95 only. The model indicates that the tangential velocity in the reactor during a fast idle is approximately $110 \mathrm{~m} / \mathrm{s}$ and far exceeds the desired velocity of $20 \mathrm{~m} / \mathrm{s}$. As a result, the inlet flow area to the reactor may need to be varied and controlled to maintain the proper tangential velocity in the reactor. Furthermore, the engine power and throttle air mass flow rate have increased by a factor of 4.1 over the minimum flow rate case, indicating that the engine air inlet area (i.e., the engine throttle or idle air control valve) may have to be controlled during cold start. The required fuel flow rate and capacity of the modeled POX reactor is substantially higher than that of the prototype tested in Phase I, suggesting that a larger reactor is required. The thermal load on the heat exchanger for this maximum case was $9 \mathrm{~kW}$. This amount of heat, which accounts for reactor and heat exchanger heat losses, can be easily managed by a small heat exchanger operating on a steady-state basis. This also indicates that a passive, thermal capacity heat exchanger could adequately cool the POX products before they enter the engine inlet manifold provided the POX reactor operates intermittently for only a few seconds at a time. 


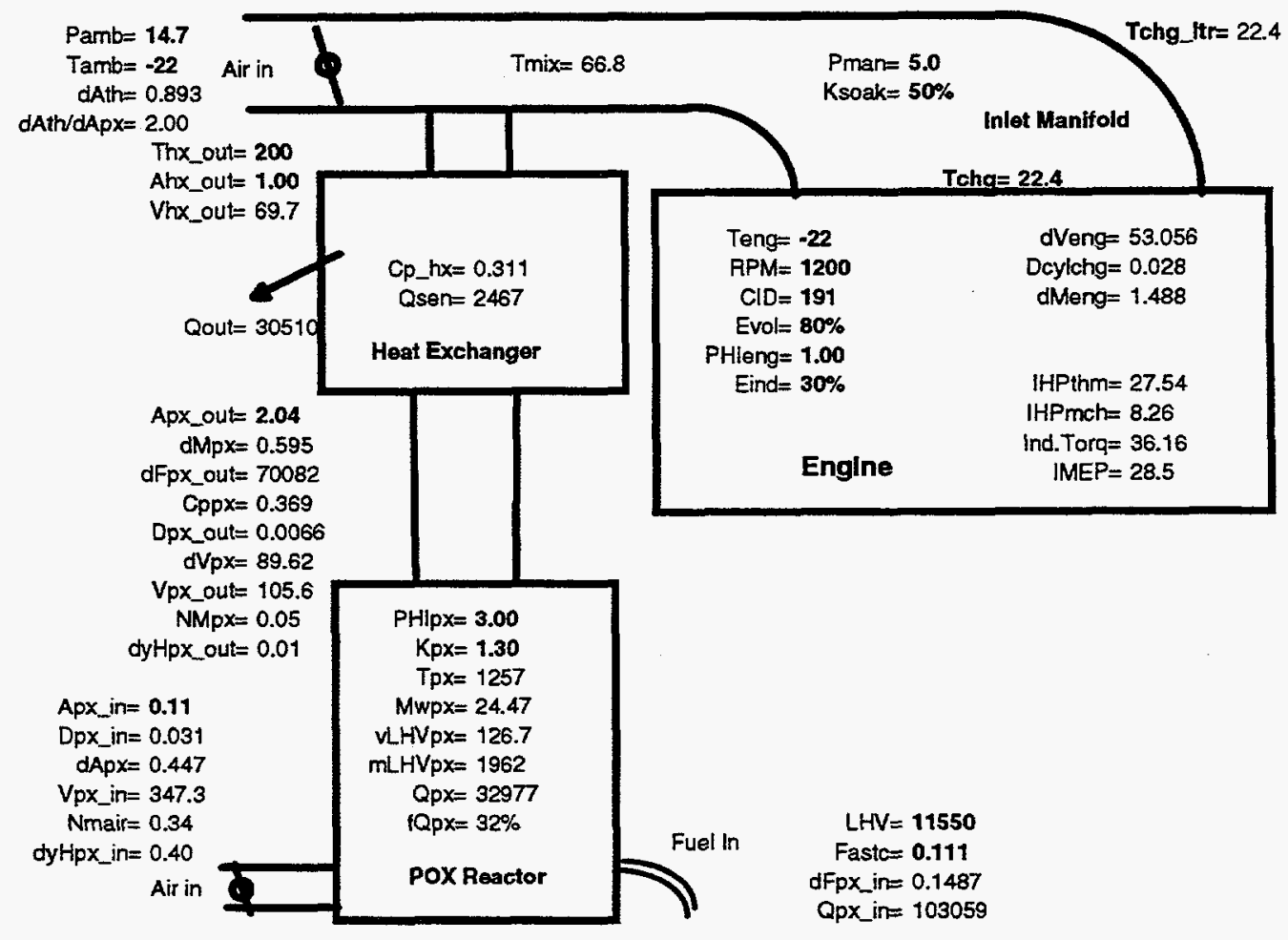

Figure 2-3: Model for Maximum Flow (Fast Idle) Case

\subsubsection{Design Implications of Model Results}

The design changes and observations made as a result of running the model follow:

- The POX reactor can provide sufficient energy at even the lowest cranking speed to overcome engine friction and accelerate the engine.

- The POX reactor inlet flow area may have to be varied with engine speed to maintain acceptable inlet velocities.

- The overall size of the POX reactor has to increase slightly from that of the prototype tested during Phase I.

- The heat exchanger requirement to maintain a maximum POX reformate temperature of $95^{\circ} \mathrm{C}$ appears to be manageable.

- Flow velocities, dynamic head, and Mach numbers throughout the system are modest, indicating that internal pressure drops in the system will be manageable.

- Active control of the air flow through the engine throttle may be required to maintain an engine fuel/air $\phi$ of 1 . 
- Changes in the reactor fuel/air $\phi$ from the nominal value of 3 have little impact on the POX reactor design. Operating the reactor richer reduces the heat exchanger load substantially.

\subsection{System Hardware}

The prototype integrated cold-start POX system appears in Figure 2-4. The main hardware components that were designed, fabricated, and assembled to form the complete system include the POX reactor, the heat exchanger, and two transition ducts.

\subsubsection{POX Reactor}

The POX reactor is a compact, under-the-hood combustion device that converts liquid fuel into gaseous fuel. Based on the analytical model results, modifications were made to the POX reactor. The overall size of the POX reactor was increased slightly from that of the prototype tested during Phase I. The reactor, formerly $10 \mathrm{~cm}$ long and $4 \mathrm{~cm}$ in diameter, is now $15 \mathrm{~cm}$ long and $6.7 \mathrm{~cm}$ in diameter (see Figure 2-5). This modification was made to accommodate the engine's estimated fueling requirements during idle. In subsequent designs it may be possible to reduce the size of the POX reactor by optimizing the fueling strategy (e.g., starting the engine on reformate and transitioning to liquid fuel once the engine

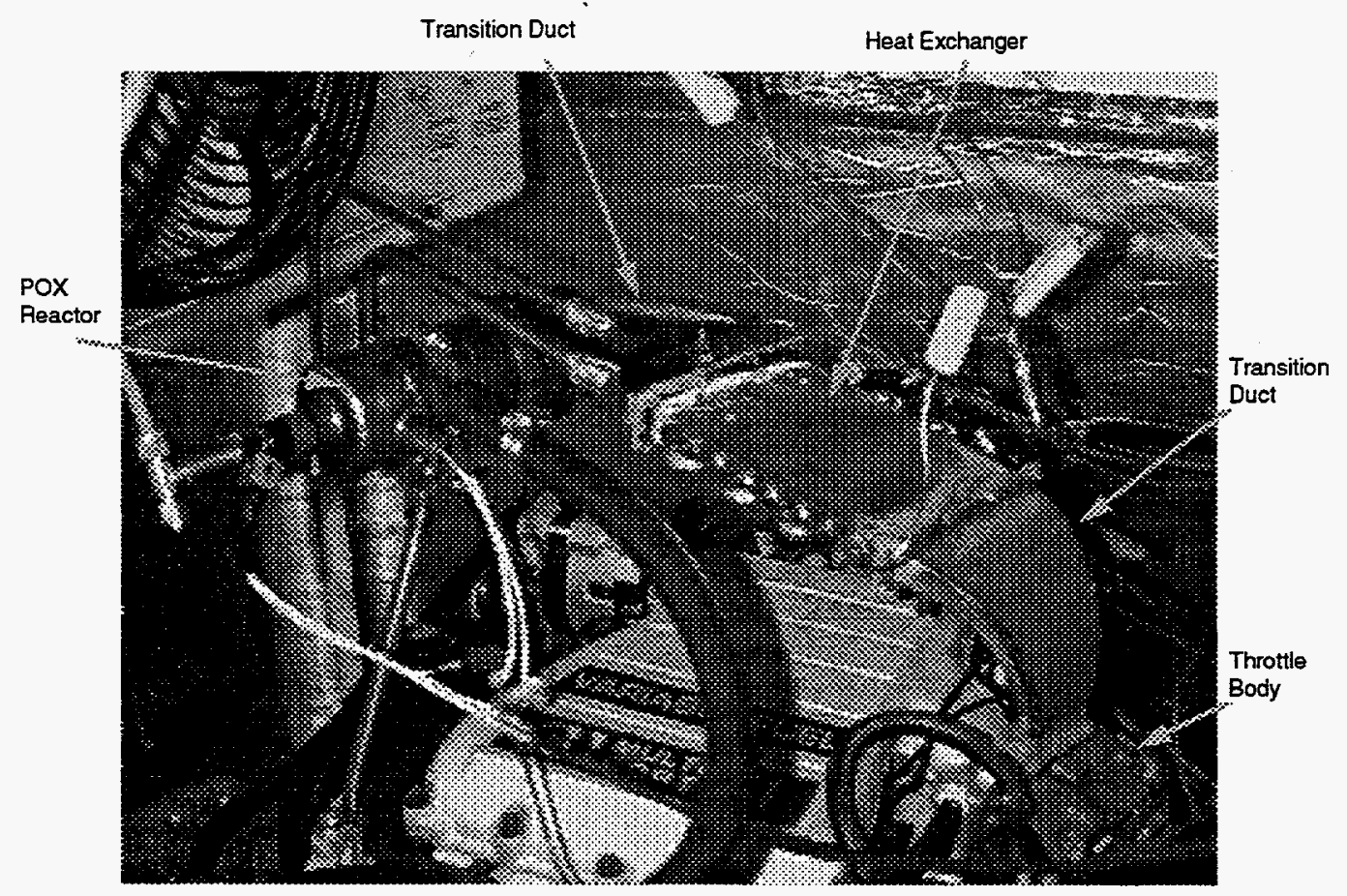

Figure 2-4: Integration of the Cold-Start System with the 1992 3.1L Chevrolet Lumina Flexible-Fuel Engine 


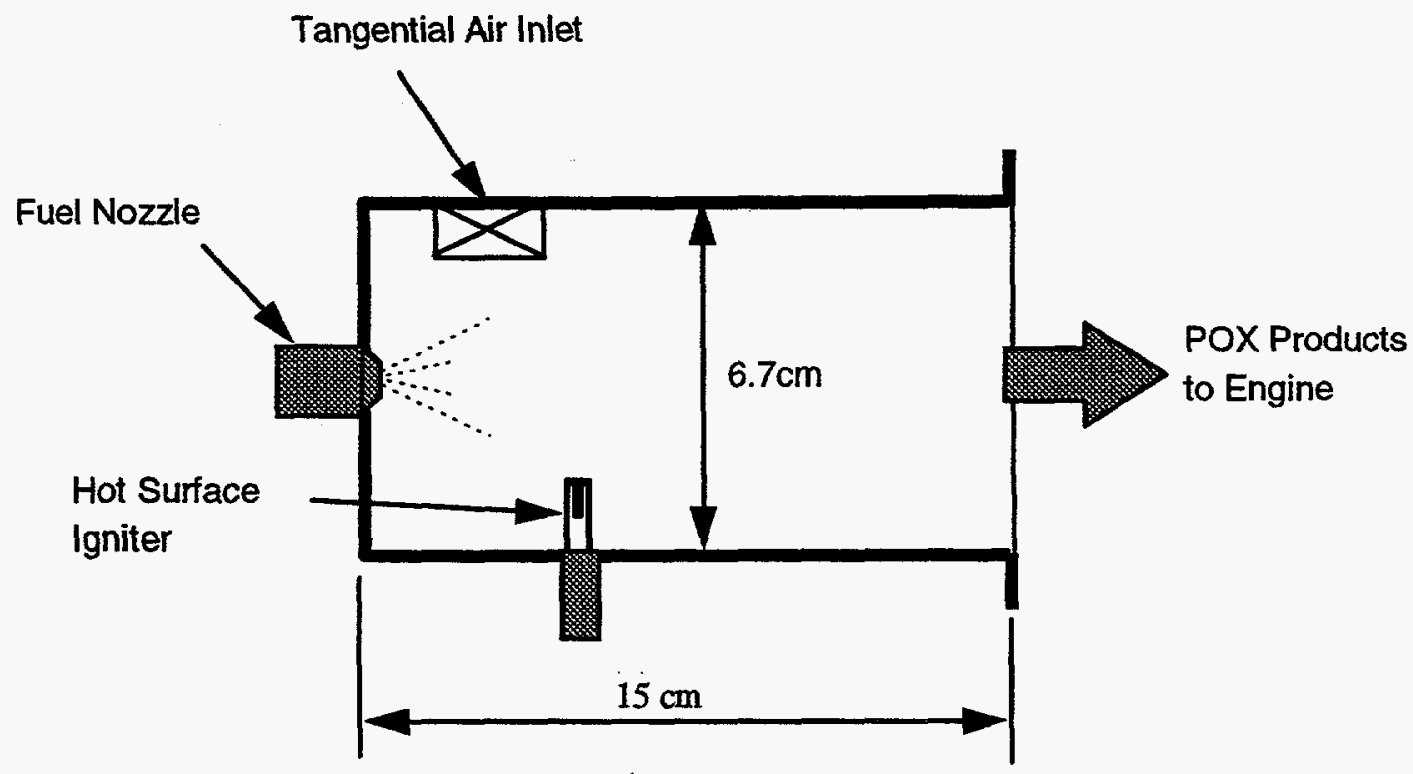

Figure 2-5: Prototype Cold-Start POX Reactor Schematic

reaches idle). Changing the proposed fueling strategy whereby cold-startability and emissions are improved requires in-depth knowledge of the ECM.

In the interest of simplicity, the prototype cold-start POX reactor was not insulated or cooled. Phase I testing of the prototype indicated that chamber surface temperatures reached an equilibrium value of approximately $260^{\circ} \mathrm{C}$. This temperature is compatible with under-hood conditions. In normal operation, of course, the device will be required to operate for only a few seconds and will not reach thermal equilibrium.

The reactor is equipped with a conventional pulse-width-modulated automotive fuel injector, the same model as that found in the GM 3.1L V6 engine being used to conduct the cold-start experiments.

POX ignition is provided by a compact hot-surface igniter commonly found in residential gas-fired heating equipment. This device consists of a silicon carbide element that is resistively heated to more than $1,500 \mathrm{~K}$ (more than $3,000^{\circ} \mathrm{F}$ ). These devices operate on 12 volts and require modest power input (approximately $30-40 \mathrm{~W}$ ). The igniter is inserted radially through the combustion chamber wall to ignite the E95 and air mixture. The igniter is located such that the liquid fuel spray does not impinge on the silicon carbide element. 


\subsubsection{Heat Exchanger}

Under steady-state operation, $\mathrm{POX}$ reformate temperatures can reach $650^{\circ} \mathrm{C}$. Even though steady-state operation of the final version of the cold-start POX reactor is unlikely, a heat exchanger is included in this experiment in anticipation of extended POX operation during experimental optimization. This provides considerable flexibility and convenience in conducting the experiments. The heat exchanger will ensure that the reformate flowing into the intake manifold is at or below $95^{\circ} \mathrm{C}$. Reformate below this temperature limit will increase the fuel gas density and ensure compatibility with intake system materials. The heat exchanger is an active system with coolant running through the coils as hot reformate passes over them. To simplify the integrated cold-start system, the active cooling loop will remain independent of the engine coolant system, although in future designs the reformate may be cooled via the engine coolant loop. We anticipate integrating a passive heat exchanger into the final on-engine cold-start system (which will only operate for a few seconds). This will provide for a much simpler system while still ensuring that relatively cool reformate enters the manifold.

\subsubsection{Transition Ducts}

Two transition ducts are required to complete the integrated system. The first joins the reactor and the heat exchanger. The conical tapered shape directs the counter-clockwise swirling reformate into the heat exchanger. The second joins the heat exchanger and the engine. The cooled reformate is introduced just downstream of the engine throttle body. A 1.3-cm wide "shim" slips easily inbetween the throttle body and the intake air manifold. The reformate fills the hollow shim that surrounds the perimeter of the intake air passage. A ring of the same size inner diameter permits the reformate to pass through its holes and into the stream of air being drawn past the throttle body and into the intake manifold.

\subsection{Shakedown Tests}

Following the fabrication and assembly of the cold-start POX system, a series of steady-state shakedown tests was conducted to verify correct operation of the system under simulated cranking and fast idle conditions. These tests were performed before mounting the system on the engine. The experimental arrangement is illustrated in Figure 2-6. Combustion air was supplied via a control valve and a rotameter, to allow precise monitoring and control of POX conditions. The E95 was supplied from a tank by a fuel pump. The fuel was recirculated to the tank to allow control of fuel pressure to the atomizer. A PC equipped with LabView data acquisition and control (DAC) software was programmed to control the fuel injector. A control program developed for these tests allows the user to set the injector pulse width and thereby the fuel delivery rate. This software was subsequently used as part of the integrated cold-start POX control system. The injector fuel delivery rate was correlated to the injector pulse width. This correlation was determined by varying the injector pulse width while collecting the delivered fuel in a graduated cylinder for a fixed period. The delivery pressure at the injector was fixed at approximately $45 \mathrm{psig}$. 


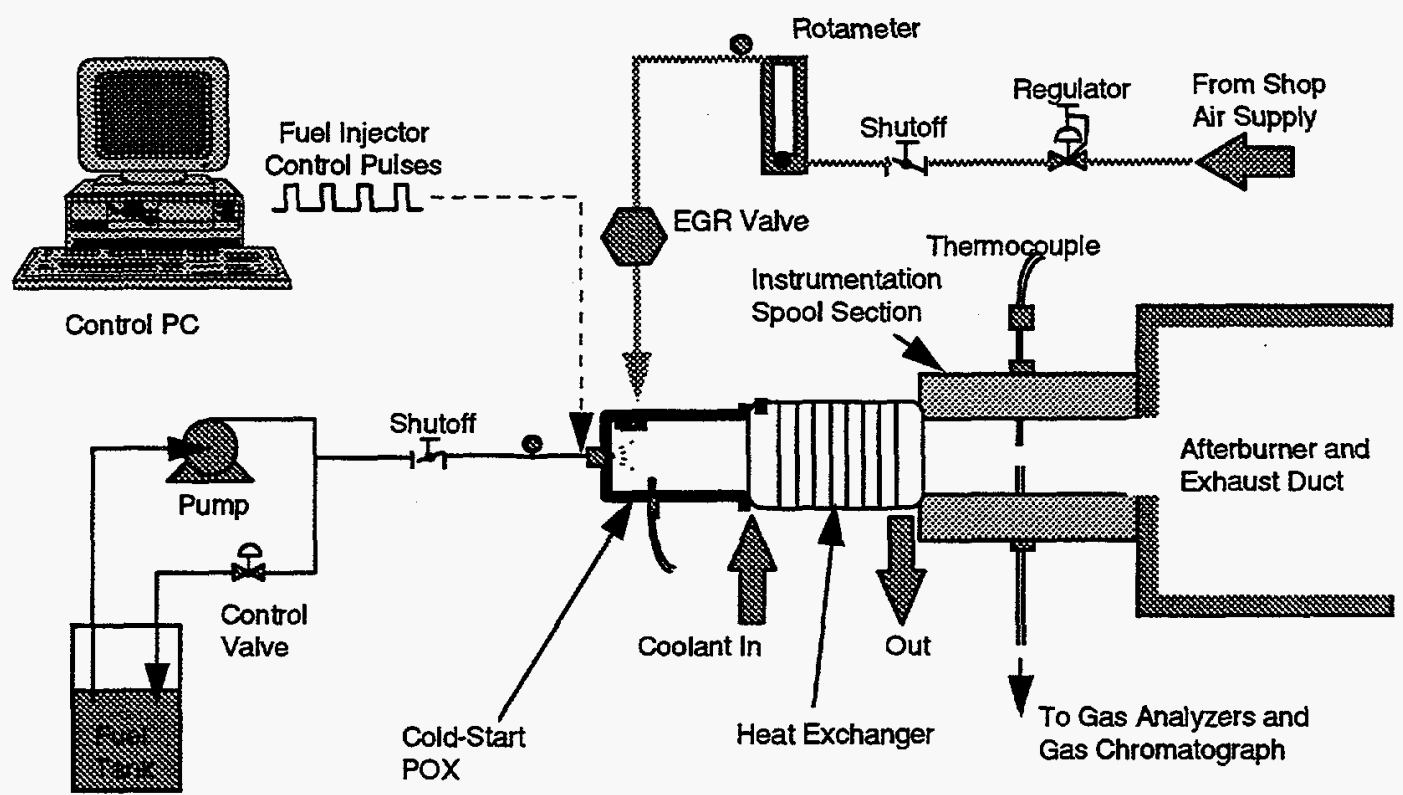

Figure 2-6: Experimental Arrangement for Prototype Cold-Start Device Shakedown Tests

Air and fuel temperatures were measured just upstream of the POX using Type-K thermocouples. The surface temperature of the POX reactor was also measured using a Type-K thermocouple.

The combustion products from the POX reactor flowed through the heat exchanger and into a spool section where a thermocouple and a ceramic gas sample probe were located. The products then entered an afterburner/cleanup chamber, in which the fuel gas from the POX was burned. The resulting products were then quenched with a water spray and left the building via a stack.

The sample gas extracted from the POX products was cooled to approximately $120^{\circ} \mathrm{C}$, then conveyed via a heated sample line to a heated filter and sample pump. The sample was then dried in a Permapure membrane dryer and metered at constant pressure to a set of gas analyzers. Continuous analysis for oxygen $\left(\mathrm{O}_{2}\right)$, $\mathrm{CO}$, carbon dioxide $\left(\mathrm{CO}_{2}\right)$, oxides of nitrogen $\left(\mathrm{NO}_{\mathrm{x}}\right)$, and $\mathrm{HC}$ was conducted. $\mathrm{Bag}$ samples were also obtained for subsequent off-line analysis using gas chromatography.

A limited series of checkout tests was performed, primarily to verify that the new system performed similarly to the first prototype reactor tested in Phase I. No attempt was made to conduct a set of parametric tests. The POX reactor was operated at a nominal $\Phi$ of 3 , as it would be during the integrated engine tests; however, the whole system operated above rather than below atmospheric. (Recall that the cranking and idling engine would draw air in through the POX reactor as it does through the engine air filter.) Excursions in fuel and air flow were imposed to verify flame stability during startup transients. 
The conclusions of the steady-state bench tests were as follows:

- The POX reactor ignites readily and operates stably over a wide range of fuel inputs (approximately 10 to $40 \mathrm{~kW}_{\mathrm{t}}$ ) and equivalence ratios (approx. 2 to 5).

- The design POX reactor air and fuel flow rates are easily achieved with the EGR valve and the automotive fuel injector.

- The POX reactor yields enough reformate to easily satisfy engine fueling requirements during cranking and fast idle.

- The heat exchanger, with a maximum coolant flow rate of $0.8 \mathrm{~L} / \mathrm{min}$, can cool $650^{\circ} \mathrm{C}$ reformate to $70^{\circ} \mathrm{C}$ during cranking and $750^{\circ} \mathrm{C}$ reformate to $120^{\circ} \mathrm{C}$ during idle. It is unlikely that these temperatures would be observed during the integrated engine tests because the POX reactor is unlikely to reach steady-state before the test is over. Based on the Phase I cold-start test results, the POX is expected to operate for fewer than 20 seconds.

\subsection{System Controls}

Both the ECM and a stand-alone PC-based controller will control the cold-start system. By employing the PC, the complexities associated with modifying ECM programs at this stage can be avoided. A PC equipped with Lab View DAC software will be integrated into the engine control scheme making use of engine sensors, such as manifold air pressure and engine speed, and sending signals to control POX reactor-related devices such as the exhaust gas recirculation (EGR) valve, fuel injector, and hot surface igniter. The signal inputs needed to aid in the communication between the ECM, PC-based controller, and integrated hardware are listed in Table 2-2.

The PC will control POX reactor fuel metering. To open and close the reactor injector, the vehicle battery will supply 12 volts to a high-speed relay in series with the injector, while the PC sends a 5-volt square wave to the relay. The engine PFIs will continue to be controlled by the ECM. Engine fuel metering is based on manifold air pressure, intake air temperature, coolant temperature, and engine speed sensor readings when the engine operates in "open-loop" mode but is based on the exhaust $\mathrm{O}_{2}$ sensor once the engine switches to "closed-loop" mode because the sensor has warmed up. 
Table 2-2: Signals Monitored by the PC-Based Controller/DAC

\begin{tabular}{|l||}
\hline POX System Related \\
Igniter (ON/OFF) \\
Fuel injector pulse width \\
Chamber temperature \\
Heat exchanger exit temperature \\
Coolant temperature (in/out) \\
\hline Engine Related \\
Port fuel injectors (ON/OFF) \\
Engine speed \\
Manifold air pressure \\
Ambient temperature \\
Coolant temperature \\
Exhaust temperature \\
Battery voltage \\
Idle air control valve (AB) \\
Key position (OFF/ONSTART) \\
\hline
\end{tabular}

The controls are based on the most effective cold-start fueling strategy developed in Phase I. With this fueling strategy, the POX reformate fueling rate increases as the engine speeds up, starts, and transitions to idle, so as to maintain a combustible mixture in-cylinder. Once the engine reaches idle, the PFI system is activated and the POX reformate flow rate is gradually reduced to nothing. The engine is left running on liquid E95 only. This strategy was programmed into the PC-based controller and activated at ambient temperatures below a user-specified threshold (generally $5^{\circ} \mathrm{C}$ ). At conditions above the threshold the $\mathrm{PC}$ would command the ECM to engage its default cold-start fueling strategy. The sequence of events follows:

1. Manually turn ignition to "on" position.

- POX igniter and fuel pump relay turn "on."

- Engine fuel injectors manually turned "off."

- POX igniter turns "on."

- Default POX fueling rate is set.

2. Turn ignition to "start" position; engine starts cranking.

3. POX ignites; controller ramps up POX fueling rate based on user input.

4. Engine starts firing on reformate only.

5. Controller maintains POX fuel flow, which satisfies engine fueling requirements as engine speed ramps up to a fast idle condition.

6. Turn engine fuel injectors "on" when engine reaches idle condition.

7. Gradually decrease reformate flow rate.

8. Shut POX injector "off."

9. Purge reactor with air. 
Figure 2-7 presents in greater detail the control logic followed by the PC-based controller. Only when the condition within a command box is satisfied does the PC-based controller advance to the next state. At the beginning of each experiment, the default setting for the POX fuel injector and the emergency stop threshold values had to be set. For the duration of each test, if one of the emergency thresholds (e.g., engine speed or POX chamber temperature) is surpassed, the entire experiment shuts down. The PCbased controller and the data acquisition system are one and the same. As the controller steps through each of the command states, data are stored to a buffer and then to a file at the end of the test.

\subsection{Prototype Integrated Cold-Start System Testing}

A number of experiments were conducted to demonstrate the performance of the coldstart system. The test facilities and procedures used are detailed in the Appendix. The experiments identified improvements in the system fueling strategy, in cold-startability, and in cold-start emissions.

\subsection{Test Matrix}

Upon successful integration of the prototype cold-start system with the engine, the test matrix shown in Table 3-1 was developed to demonstrate its ability to improve cold-start performance:

Table 3-1: Integrated Cold-Start System Test Matrix

\begin{tabular}{|c|c|c|c|c|}
\hline $8+14.8$ & $861=\alpha+1$ & 3. & 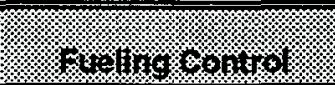 & (remprating \\
\hline 1 & $\begin{array}{l}\text { Optimization of } \\
\text { Fueling Strategy }\end{array}$ & Reformate & $\begin{array}{l}\text { Manual POX control } \\
\text { POX controller }\end{array}$ & $\begin{array}{l}30,20,5,0 \\
-5,-20,-30\end{array}$ \\
\hline \multirow[t]{2}{*}{2} & \multirow{2}{*}{$\begin{array}{l}\text { Cold-Startability } \\
\text { Improvement }\end{array}$} & E95 & ECM & 25,5 \\
\hline & & $\begin{array}{l}\text { Reformate } \\
\text { Reformate/E95 }\end{array}$ & POX controller & $\begin{array}{l}5,0,-5,-10 \\
-15,-20,-25\end{array}$ \\
\hline \multirow[t]{2}{*}{3} & \multirow{2}{*}{$\begin{array}{l}\text { Cold-Start } \\
\text { Emissions } \\
\text { Reduction }\end{array}$} & E95 & $\overline{E C M}$ & 5 \\
\hline & & $\begin{array}{l}\text { Reformate } \\
\text { Reformate/E95 }\end{array}$ & POX controller & $\begin{array}{l}5,-10,-20, \\
-25\end{array}$ \\
\hline
\end{tabular}

\subsection{Test Series 1: Optimization of Fueling Strategy}

The fueling strategy adopted from Phase I was discussed previously from a general controls logic perspective. The details, as they pertain to the test results, will now be developed. Figure 3-1 identifies the level of POX fueling and its impact on the POX reactor performance as dictated by the POX chamber temperature for a cold start at $-12^{\circ} \mathrm{C}$. During cranking when the engine port fuel injectors were disabled, the POX fuel injector was opened to $25 \%$ of its duty cycle, delivering about $0.2 \mathrm{~g} / \mathrm{s}$ of E95 to 


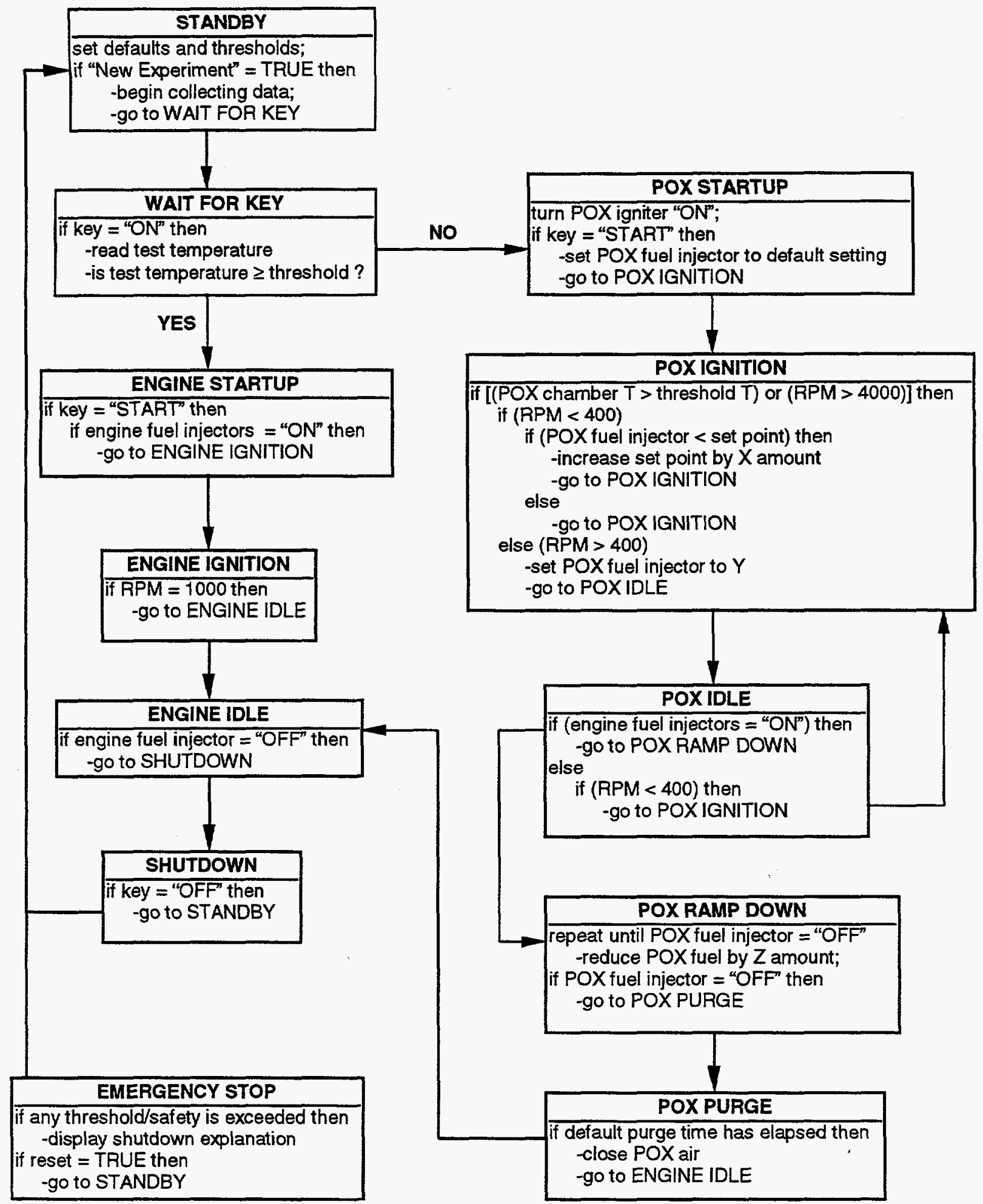

Figure 2-7: Logic Diagram of the Command States in the PC-Based Controller 
the reactor. With this strategy the POX reactor lit reliably and immediately at temperatures as low as $-21^{\circ} \mathrm{C}$. Because of hot and humid ambient conditions and limitations with the environmental test chamber, the engine could not be chilled below $21^{\circ} \mathrm{C}$. Prior testing indicated that the POX reactor would light successfully at even lower temperatures. The POX chamber temperature graphed in Figure 3-1 verifies that the reactor has lit. Once the reactor has lit and the POX chamber temperature exceeds a specified threshold $\left(200^{\circ} \mathrm{C}\right.$ in this example), the fueling rate increases dramatically to begin producing enough gaseous fuel species for the engine. The increase in fueling rate was as fast as it could be without quenching the chemical reactions within the reactor. Once the engine speed exceeded $400 \mathrm{rpm}$, the fueling rate was reduced to satisfy the engine's idle fueling requirement. In this example there was a temporary drop in engine speed. The controller's response to this was to resume ramping the fueling rate until 600 $\mathrm{rpm}$ was exceeded. At that time the POX idle fueling rate was resumed.

In many cases the engine was successfully transitioned to default PFI E95. The level of liquid fueling delivered by the engine was not measured. Its default fueling strategy during open-loop control is to monitor the engine speed, coolant temperature, and intake air temperature, and then inject as much fuel as needed to volatilize enough gaseous species for combustion. Massive overfueling typically results. Nonetheless, this approach was adopted because of complexities associated with modifying the ECM.

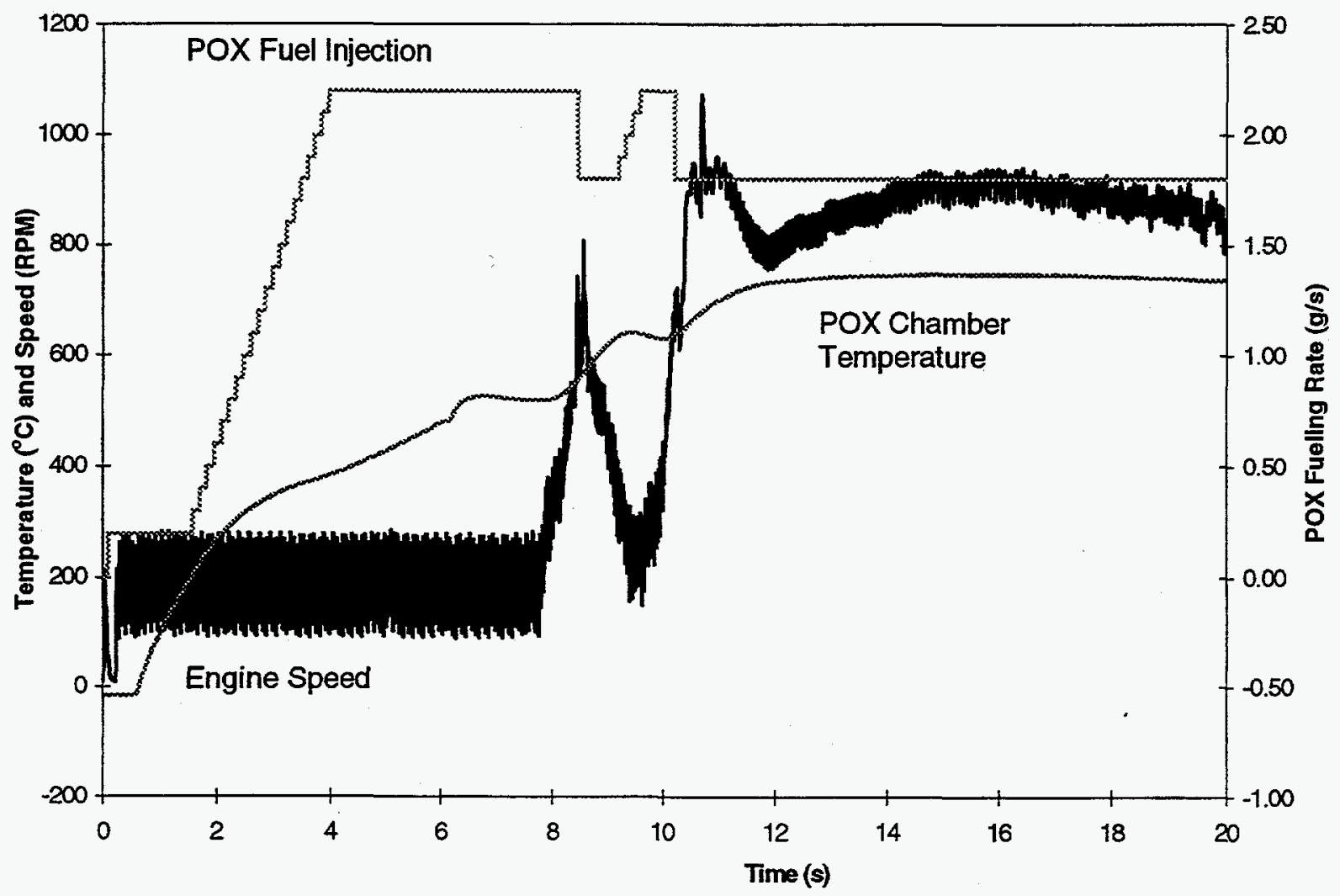

Figure 3-1: Cold Start Fueling Strategy Using Reformate Only at $-12^{\circ} \mathrm{C}$ 


\subsection{Test Series 2: Cold-Startability Improvement}

Two successful cold starts using the integrated cold-start system are pictured in Figures 3-2 and 3-3. The starts were at $-5^{\circ}$ and $-18^{\circ} \mathrm{C}$, respectively, and were achieved by a simple turn of the ignition key. In both cases the POX reactor lit immediately and produced rapid starts ( 3 and 9 seconds, respectively). The start time included approximately 2 seconds of transit time for the POX reformate to reach the intake port. By removing the heat exchanger and shortening the transition pieces, this transit time and overall start time can be reduced. The POX reformate was introduced in the intake manifold. As the engine sped up, started, and transitioned to idle, the reformate fueling rate increased accordingly to maintain a combustible mixture in-cylinder. A successful transition from POX reformate to PFI E95 is pictured in Figure 3-3. The POX reactor lit immediately and after 7 seconds of cranking the engine started and maintained an idle speed around 1,000 rpm. After 10 seconds of idle, the liquid fuel injection system was manually activated. At the same time the POX fuel injection rate was decreasing. After 6 seconds the reactor was purging, meaning there was no fuel to the POX reactor although air continued to flow through it. The engine was left idling on liquid E95 only with additional POX air. The changes in engine speed were a direct result of the in-cylinder fuel/air ratio. When the engine fueling turned on, the speed dropped until the idle air control valves adjusted to the new fueling, which included both the reformate and the liquid E95. When the reformate was ramped down, the POX air was still flowing. The engine's response was to add fuel to satisfy the given air flow to the engine, hence, an increase in speed.

Figure 3-4 shows a set of experimental data comparing the engine start time of an engine fueled according to the default fueling (E95 only) and this fueling strategy. The integrated system successfully and dramatically improved the operating temperature range of the light-duty alcohol-fueled engine. At colder temperatures the time to start will largely be a function of the engine cranking speed and its coupled effect on the transport time of the POX reformate from the intake system to the engine cylinders. Engine friction also becomes increasingly more difficult to overcome at lower temperatures.

\subsection{Test Series 3: Cold Start Emission Reduction}

There are a number of reasons why cold-start emissions from conventional gasolinealcohol-blend engines are high. Fuel volatility decreases significantly with temperature, which dictates a large amount of fuel enrichment (or overfueling) to compensate for the reduced volatility. The excess fuel and long cranking times at low temperatures result in high engine-out emission levels. Furthermore, the catalyst is ineffective until light-off. Therefore, fueling strategies that eliminate or reduce the amount of fuel enrichment and/or reduce the time to start would likely reduce cold-start emissions. 


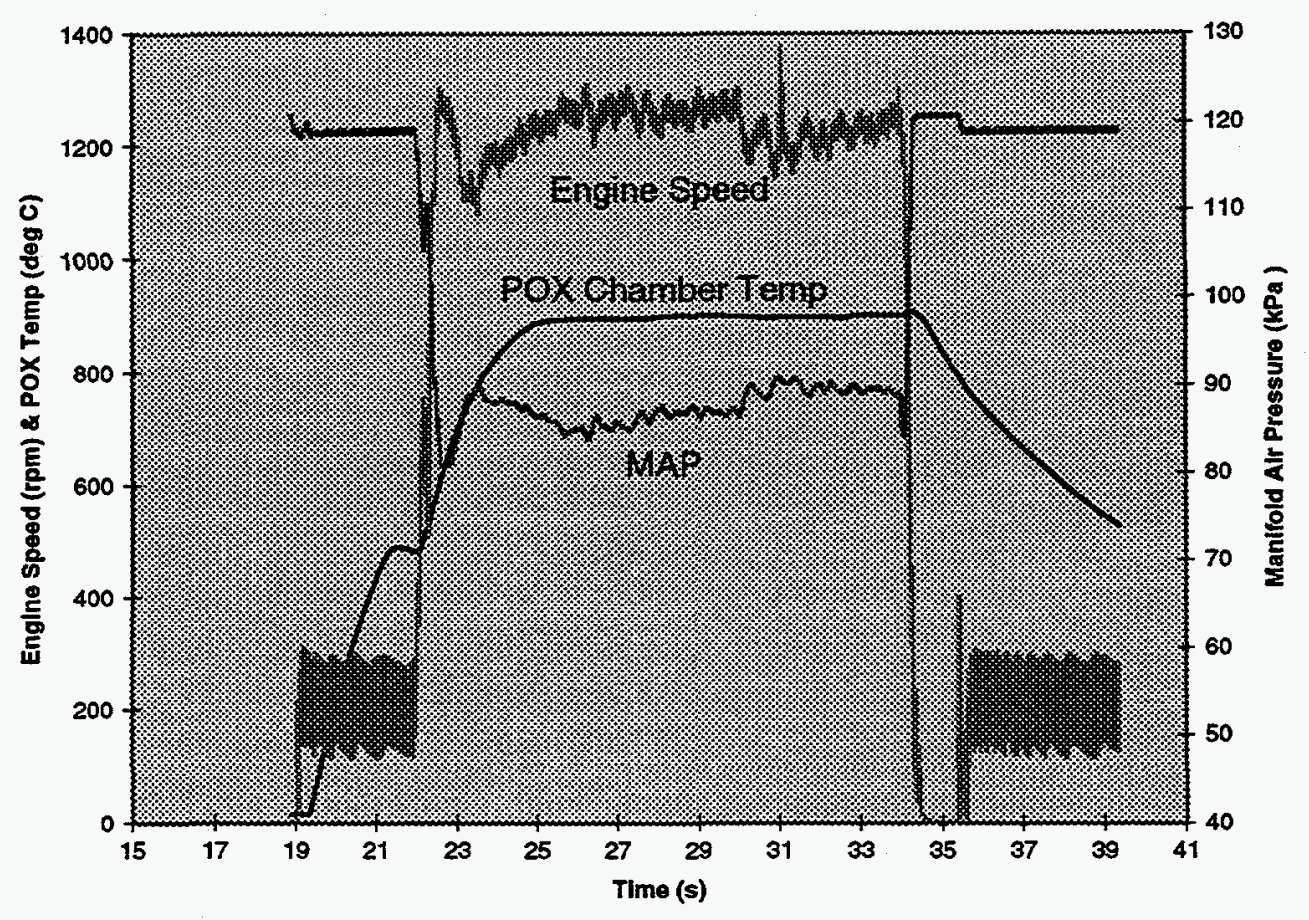

Figure 3-2: Cold Start at $-5^{\circ} \mathrm{C}$ Using the Prototype Integrated Cold-Start System

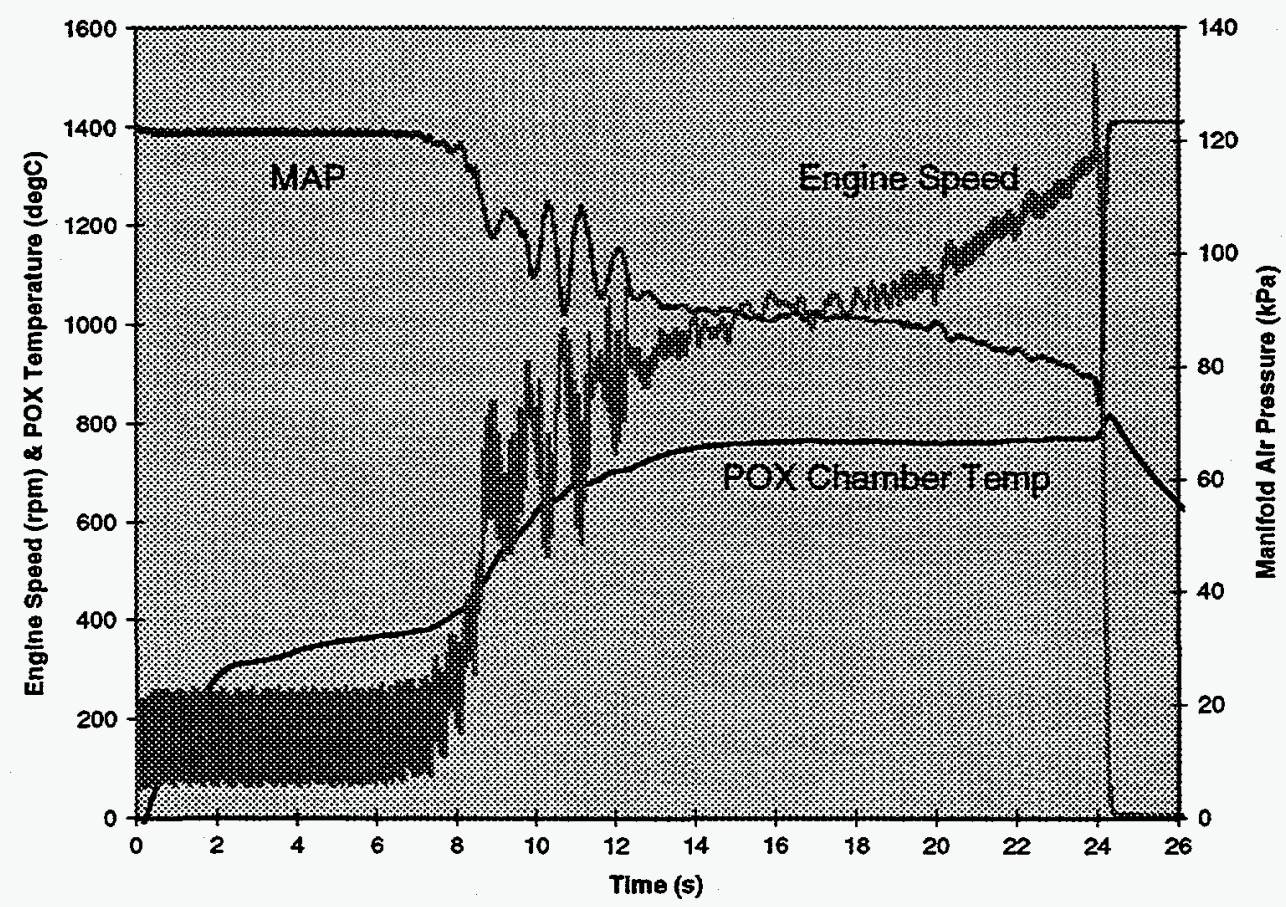

Figure 3-3: Cold Start at $-18^{\circ} \mathrm{C}$ Using the Prototype Integrated Cold-Start System 


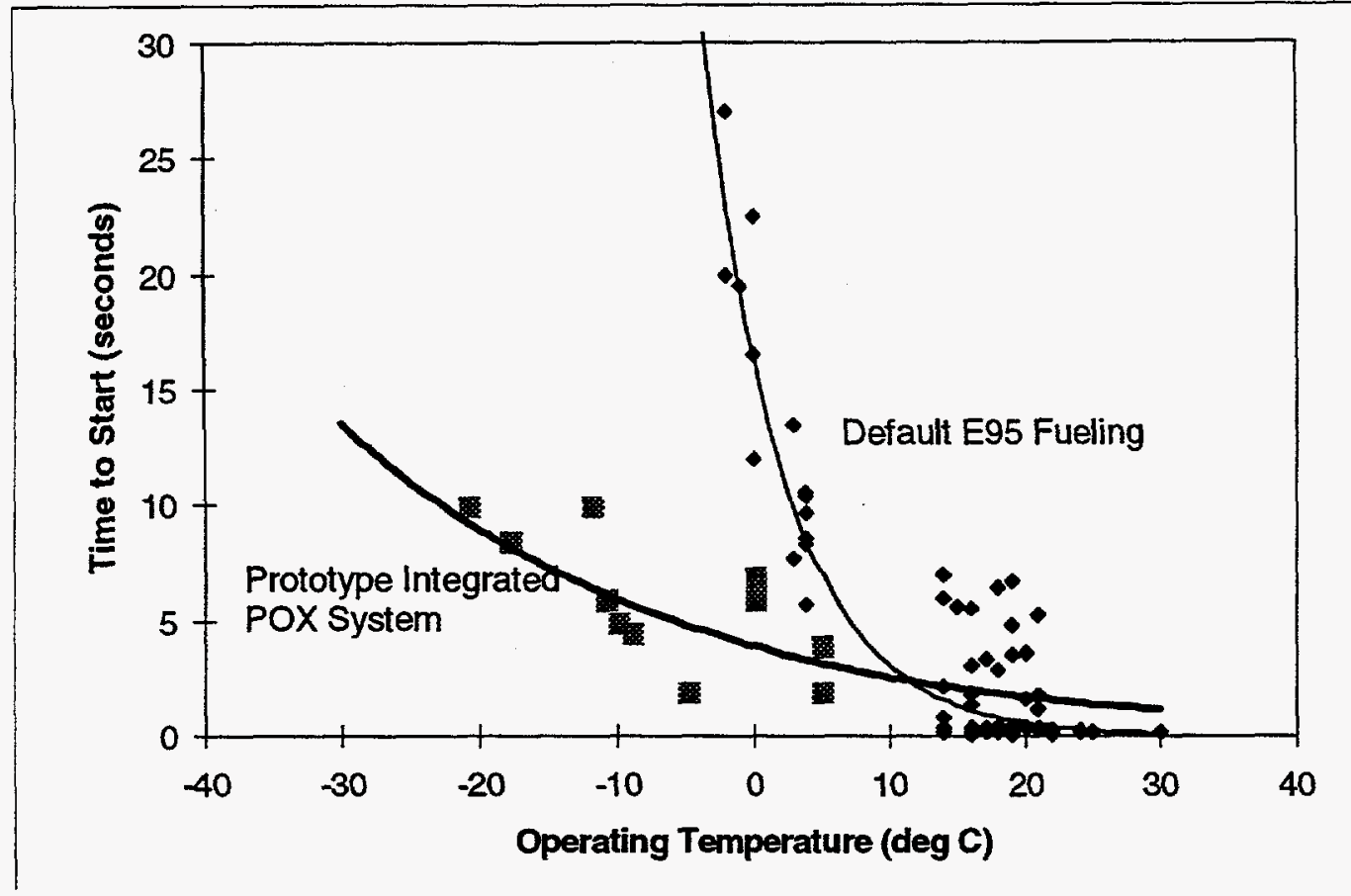

Figure 3-4: Improvement in Engine Cold-Start Performance Obtained by Starting the Engine on Reformate from the Integrated Cold-Start System

The integrated cold-start system has demonstrated that it can not only reduce the time to start, but also reduce the cold-start emissions. Figures 3-5a through 3-5c depict the online engine-out emissions for the first 50 seconds of a cold start at $5^{\circ} \mathrm{C}$. Each figure compares a baseline engine start on E95 only and an engine start on reformate with a transition to the default engine fueling strategy. The emissions data lagged compared to the engine data because of length of the emissions sample line. However, the two starts are in line with each other according to when the engine starts. The reformate-fueled engine started after 3 seconds of cranking; the liquid E95-fueled engine started after 29 seconds of cranking. The impact these two starts had on the HC emissions can be seen in Figure 3-5a. The overfueling during the baseline engine start contributed significant $\mathrm{HC}$ emissions during cranking, where levels were around $6,000 \mathrm{ppm} \mathrm{C}_{3}$, and start, where levels increased steadily. The short crank and start time for the cold-start system dramatically reduced the cold-start emissions. Even as the engine idled on reformate, the engine-out $\mathrm{HC}$ emissions were maintained around $1,000 \mathrm{ppm} \mathrm{C}_{3}$. Only when the default engine fueling started did the cold-start system's $\mathrm{HC}$ emissions increase. As shown in Figure 3-5b, the reduction in $\mathrm{CO}$ emissions was also pronounced, with an $80 \%$ reduction in the average emissions level. The $\mathrm{NO}_{\mathrm{x}}$ emissions (see Figure 3-5c) were comparable during crank and start. The baseline engine emissions increased during idle. The overall emissions reduction benefit could be even greater when the integrated cold-start system is fully optimized and integrated with the engine control unit. 

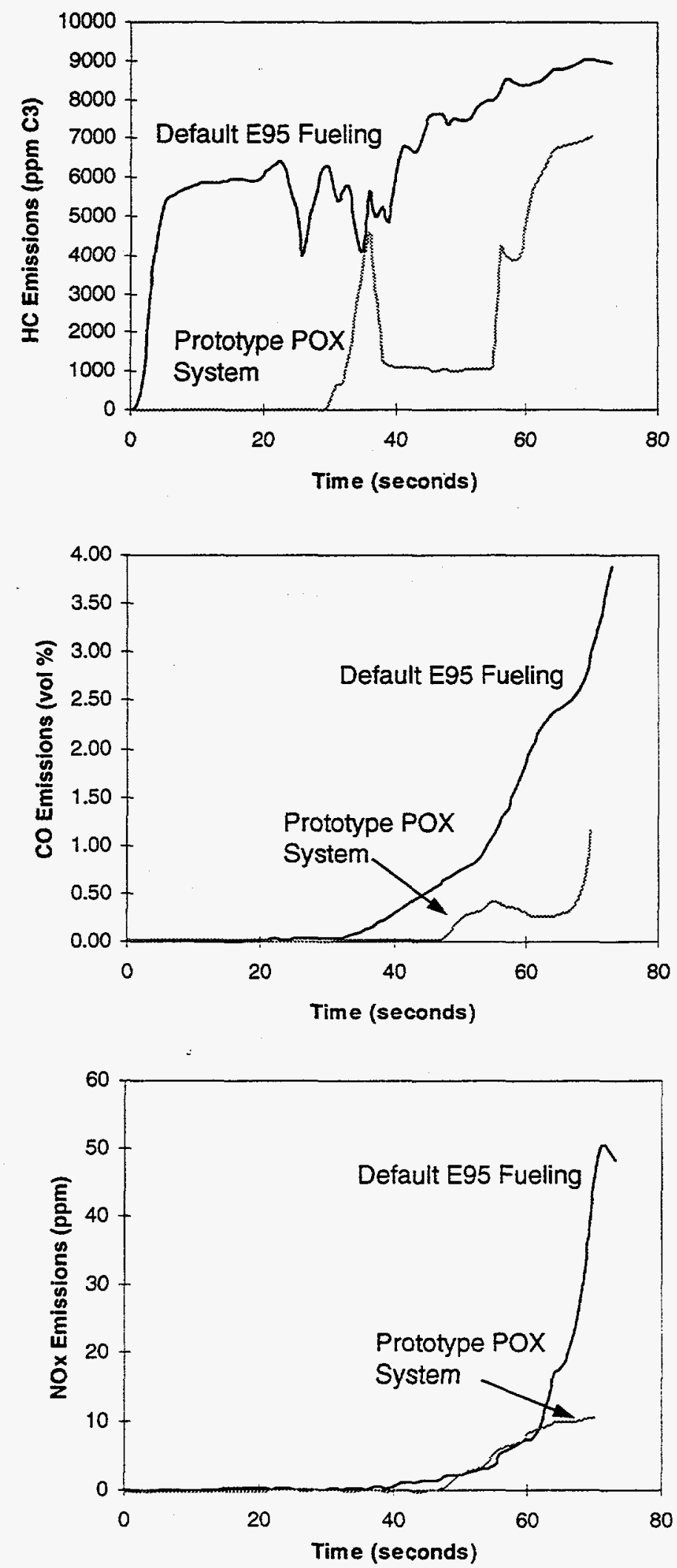

Figure 3-5: On-line Emission Measurements of Criteria Pollutants [(a) HC, (b) $\left.\mathrm{CO},(c) \mathrm{NO}_{\mathrm{x}}\right]$ Generated from Starting the Engine with the Baseline Fueling and the Integrated Cold-start System 


\subsection{System Design Update}

Based on results from the prototype integrated cold-start system testing, a number of updates were recommended. As a reference, Figure 2-1 depicts the original cold-start system. The following discussion addresses design updates for system controls and hardware.

\subsection{Controls Updates and Their Impact on Cold-Start Performance} Initially the PC-based controller was developed to control the cold-start POX system without embarking on the complexities associated with modifying ECM programs. The HC emissions data presented in Figure 3-5a indicate that integration of the PC-based controller and ECM are crucial for emissions performance. When the engine was started on reformate only, the $\mathrm{HC}$ emissions were lower than if it were started on PFI E95. When the transition from reformate to PFI E95 occurred, the increase in $\mathrm{HC}$ emissions was substantial and unacceptable. The design update would require modifying the engine's fueling strategy to reduce the overfueling that occurred when the fuel injectors were activated. Because the engine computer was operating open-loop, the intake air and coolant temperature sensors still reported that overfueling was needed because of the cold ambient conditions. Furthermore, the heat from the reformate could be better used to assist the evaporation of the reduced fueling during the transition. With these updates the engine performance at idle is expected to smooth out, unlike what was captured in Figure 4-1.

\subsection{Hardware Updates and Their Impact on Cold-Start Performance}

\subsubsection{POX Reactor}

Initially the POX reactor increased in size, and air inlet ports were added. The reactor, formerly $10 \mathrm{~cm}$ long and $4 \mathrm{~cm}$ in diameter (during Phase $I$ testing), became $15 \mathrm{~cm}$ long and $6.7 \mathrm{~cm}$ in diameter. The POX reactor size could be reduced down to its Phase I dimensions provided the PC-based controller was integrated with the ECM as described in the previous section. By changing the fueling strategy of starting the engine on reformate only and transitioning to PFI E95 at idle to where the engine shares the fueling responsibility during the transition to start, the reactor could return to Phase I prototype size. This design update would not only maintain the cold-start performance but also improve the drive-away performance. Once a driver starts the car, just seconds are usually required before the car goes from a no-load to a load condition. Stalling would occur if the engine's fuel demand could not be met immediately. With the PFI E95 already fueling the engine on a minimal level, the ECM could respond quickly to the demand. 


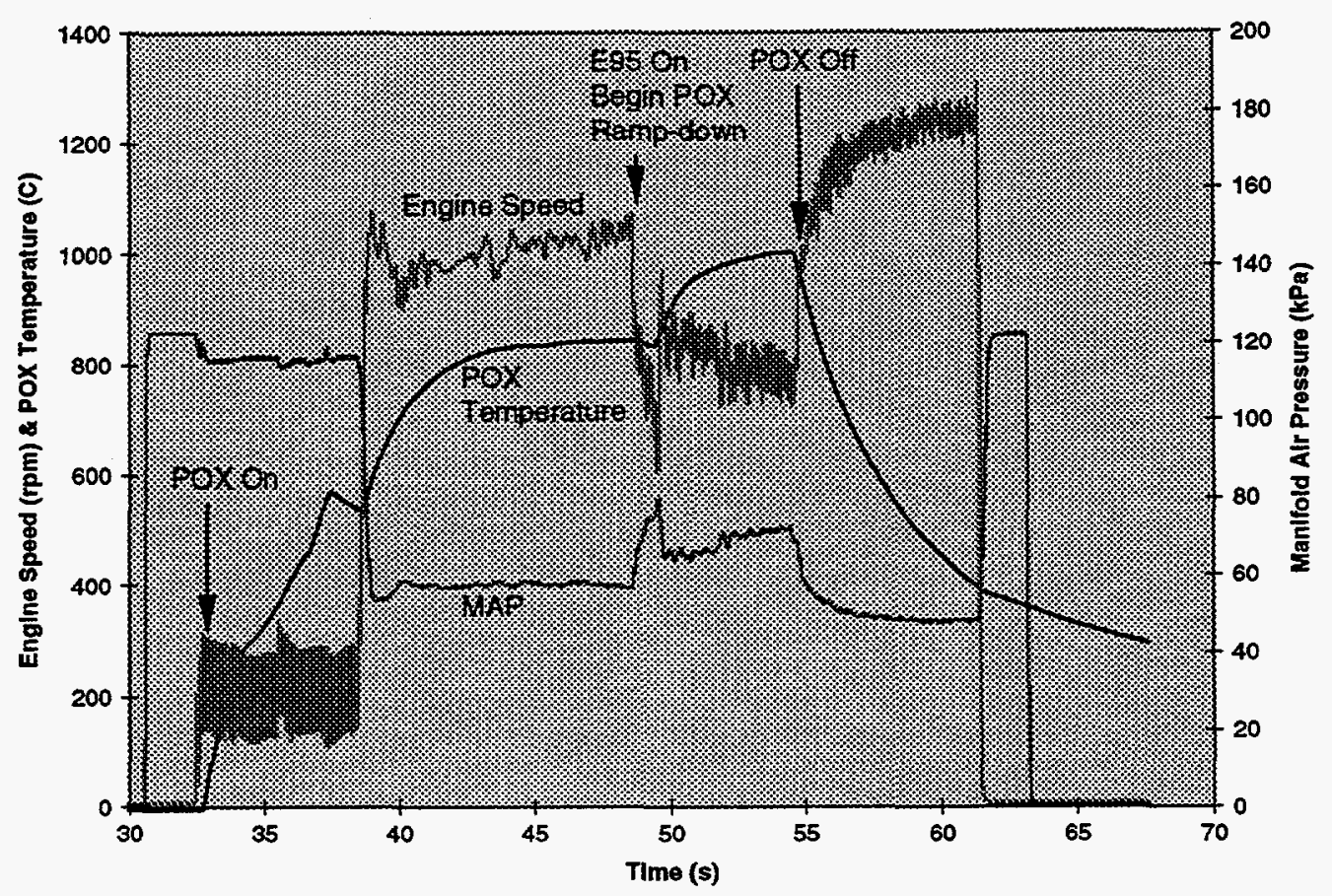

Figure 4-1: Cold Start at $-10^{\circ} \mathrm{C}$ Using the Prototype Integrated Cold-Start System with a Transition to PFI E95

Test results indicated that only one tangential air inlet port was required for POX reactor operation. We initially believed that tight control of the air flow to the POX reactor was required to maintain production of a rich mixture (POX reactor equivalence ratio $=3.0$ ) in the reactor that could fuel the engine. When the EGR valve was removed from the system because it malfunctioned at low temperatures, we proved that only "on/off' control of the POX air was required. As the engine cranked and started, the air being drawn through the reactor always remained in the right proportion (1:2) with the engine air flow. A rotameter was substituted for the EGR valve only as a means of monitoring the air flow through the reactor. Unregulated POX air flow rates ranged from about $100 \mathrm{scfh}$ at cranking to about $400 \mathrm{scfh}$ at idle. This corresponded to POX equivalence ratios of approximately 2 during ignition and approximately 4 during idle. This modification simplifies the packaging and controls. Without the extra inlets, the reactor could nestle closer to the engine hardware. Furthermore, the need for a complicated look-up table and valve to control the airflow to the POX reactor is eliminated. A solitary on/off valve for the remaining inlet is all that is required on the updated design. The engine EGR valve might become the needed on/off valve, because the valve is usually closed during cold engine operation and below idle speed, the two conditions when the engine would be fueled on reformate. The PC could deactivate the EGR sensor, use a three-way valve to direct the reformate into the EGR passage, and reactivate the EGR sensor once the POX reactor shuts off. 


\subsubsection{Heat Exchanger}

Initially a heat exchanger was included to ensure that reformate entering the intake port was below $100^{\circ} \mathrm{C}$. Figure 4-2 illustrates typical exit temperature curves for the POX chamber and active heat exchanger. Under steady-state operation, POX chamber temperatures reached as high as $1,000^{\circ} \mathrm{C}$. However, in an optimized and fully integrated system (with respect to controls), steady-state operation of the POX reactor is unlikely. POX chamber temperatures are not expected to exceed $800^{\circ} \mathrm{C}$. Early in the testing we also observed that coolant circulating through the heat exchanger was not needed for the first 20 seconds of POX reactor operation, because there was enough contact with cold metal that the hot reformate $\left(200^{\circ}\right.$ to $\left.800^{\circ} \mathrm{C}\right)$ remained below $200^{\circ} \mathrm{C}$. The metal mass of the heat exchanger acted as a passive heat exchanger. The proposed design update is to substitute a passive system for the current active design that is effective but reduces the residence time. For instance, the reformate might first pass through a copper mesh that will act as a flow straightener and then flow through a channel full of copper pellets. If the reactor were operated for longer periods ( 25 seconds or more, though this is not expected during typical use), some form of heat exchanger (active or passive) would be needed to prevent a loss in engine volumetric efficiency. In this case, it may be more desirable to use the waste heat by connecting to the engine coolant system. For the most part, some heat from the POX reactor helps warm the intake port and valve in preparation for the transition to PFI E95.

An overall shorter cold-start system would help reduce the reformate transit time from the reactor to the cylinder. The data in Figure 4-2 illustrate a 10-second time to start. A shorter system could reduce the start times (see Figure 3-4) by 1 second, shifting the POX system curve downward.

\subsubsection{Transition Ducts}

The two transition ducts that were part of the system tested in Task 3 are pictured in Figure 2-4. The first coupled the POX reactor and the heat exchanger. This duct would be modified to fit the updated designs for a smaller reactor and passive heat exchanger and would be as short as possible. Its shape and orientation would most likely change to satisfy packaging and mounting requirements. The second transition duct couples the heat exchanger and the engine. Updating its design would entail shortening it slightly. If the engine's EGR valve were used to control the POX reactor inlet air, its passage into the intake manifold might also be used, provided the pressure drops were low. 


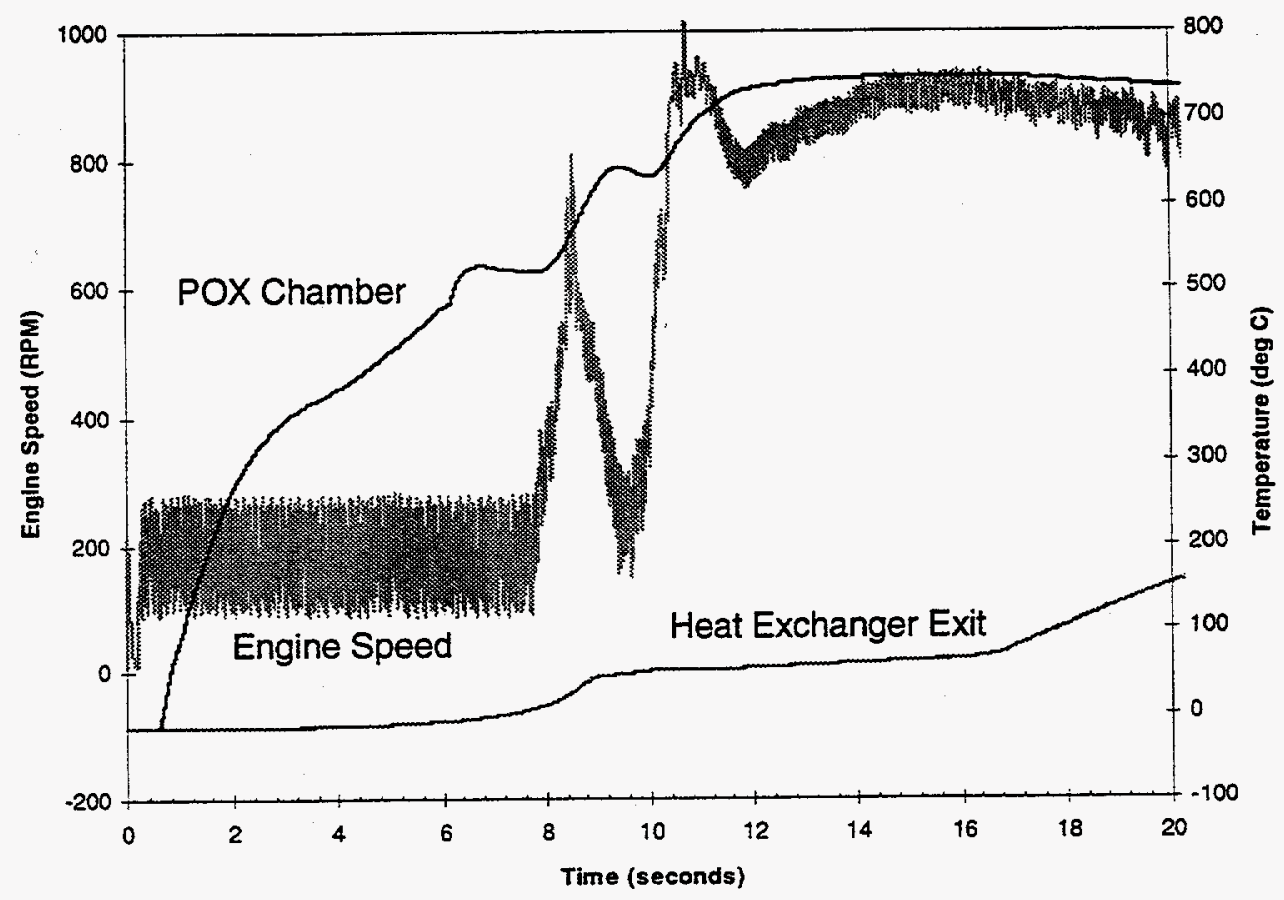

Figure 4-2: POX Chamber and Heat Exchanger Exit Temperatures during a Cold Start at $-12^{\circ} \mathrm{C}$ Using the Prototype Integrated Cold-Start System

\subsection{Impact on Compatibility and Commercialization}

The prototype integrated cold-start system's compatibility with other engines is related to accessing the intake manifold downstream of the engine throttle body. If it is difficult to add a transition piece behind the throttle body, an EGR valve mounted in the manifold could serve as an introduction point for the reformate and as an on/off valve for the POX reactor air flow. Although distribution of the reformate from the intake manifold to the cylinders is not well understood, it is likely to be similar to EGR in the manifold. Retrofitting a vehicle with this system is feasible provided the controls algorithm could be downloaded to the ECM. Controls compatibility issues are not expected.

The cold-start POX system has been tested using several standard automotive components (Figure 4-3). Following the design updates the standard components (fuel injector, EGR valve, and glow plug) are still preferred because of their performance, availability, and durability. The system's hardware cost is an estimated $\$ 50$ to $\$ 100$. Using an EGR valve could reduce this cost. 


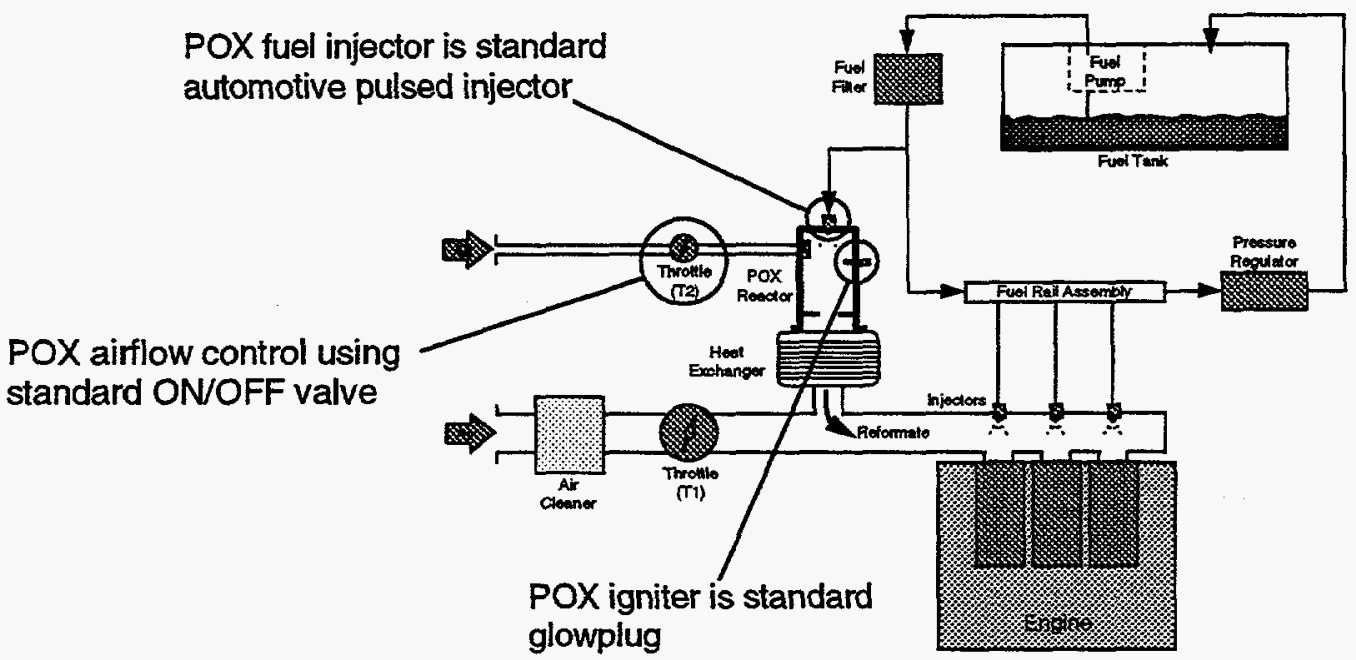

Figure 4-3: Standard Automotive Components Used by the Prototype Integrated Cold-Start System

\subsection{Conclusions}

The experimental validation of a prototype integrated cold-start system for alcohol-fueled engines has been successfully completed. Specifically, we have:

- Designed an extremely simple and compact prototype POX reactor and demonstrated its operational performance on liquid E95 at low temperatures. The POX reactor:

$\diamond$ Produces a reformate composition that is an effective fuel for engine cold starts and idle operation

$\diamond$ Does not require pre-vaporized fuel-operation with liquid fuel greatly simplifies fuel delivery and metering

$\checkmark$ Uses liquid fuel pressures that are compatible with normal automotive fuel pumps

$\diamond$ Demonstrates rapid ignition under cold conditions $\left(-20^{\circ} \mathrm{C}\right)$

$\diamond$ Operates stably over a wide range of equivalence ratios $(1<\Phi<5)$

$\checkmark$ Provides great flexibility in developing a control strategy for supplying variable flow rates of reformate for ramping up engine speed during very cold starts because of its wide range of stability and turndown

$\diamond$ Operates at temperatures that are modest and compatible with engine applications

- Demonstrated "turn-key" operation of a prototype integrated cold-start system 
- Demonstrated rapid engine starts (less than 10 seconds) and transition to sustained idle at very low temperatures $\left(-20^{\circ} \mathrm{C}\right)$

- Demonstrated successful starts on POX reformate and smooth transitions to $100 \%$ PFI E95 within 10 seconds of engine start down to about $-20^{\circ} \mathrm{C}$

- Demonstrated significant reduction in $\mathrm{HC}$ and $\mathrm{CO}$ emission rates during the first 45 seconds of cranking and idle using POX reformate

- Demonstrated the wide ignition limits of typical POX reformate species under engine cold-start conditions (as low as $-20^{\circ} \mathrm{C}$ ).

From the test results, a number of cold-start system design updates were suggested. Ultimately the current "works-like" system needs to be further developed into a "looks-like and works-like" system. "Looks-like" developments would include packaging for under-the-hood operation and meeting standard auto industry specifications. "Works-like" developments would include optimizing the fueling strategies for further emissions benefit and absorbing the PC-based controller into the ECM. Most of the effort in the next stages is associated with control system development.

The continued development of an integrated POX system in a light-duty vehicle engine as a component of the fuel system offers perhaps the best opportunity for improving cold startability and thereby solving one of the biggest hurdles facing neat alcohol fuels. This would then pave the road for more widespread acceptance of alcohol fuels, especially ethanol, which are emerging as preferred alternative fuels because of the superior range afforded by liquid fuels and because they can be derived from renewable resources. 


\subsection{References}

1. "Development of a Multi-Fuel Partial Oxidation Reformer for Transportation Applications," Loftus, P.J., J. H. Thijssen, E. Hainsworth, and J. Bentley, Proceedings: 1994 Fuel Cell Seminar, San Diego, CA, Nov. 28-Dec. 1, 1994.

2. "Development of a Catalytic Partial Oxidation Ethanol Reformer for Fuel Cell Applications," Mitchell, W.L., J.H.J. Thijssen, J..M. Bentley, and N.J. Marek, SAE Paper 952761, Presented at the 1995 SAE Alternative Fuels Conference, San Diego, CA, 1995. 


\subsection{Appendix: Testing Facilities and Procedures}

\subsection{Testing Facilities}

The experimental facility used to conduct the prototype integrated cold-start system testing included an ethanol-compatible test engine, an environmental test chamber to simulate cold ambient conditions, and a DAC system.

\subsubsection{Ethanol-Compatible Test Engine}

All experiments were conducted on a 1992 Chevrolet $3.1 \mathrm{~L}$ flexible-fuel vehicle Lumina test engine obtained directly from General Motors. Engine specifications appear in Table 7-1. The engine is capable of operating on various gasolinealcohol blends. An in-line fuel sensor detects fuel composition by measuring changes in dielectric constant and the injection rate is modified accordingly. All experiments used a readily available supply of E95 (95\% ethanol with 5\% gasoline, by volume). The engine was tested in a fully contained buck complete with transaxle and all engine subsystems (cooling, charging, fuel delivery system, wiring harness including engine computer, etc.). To minimize the heat losses during the cold-start experiments, the buck was kept intact rather than mounting the engine to the dynamometer.

Table 7-1: Ethanol Test Engine Specifications

\begin{tabular}{|l|l|}
\hline Model & 1992 flexible-fuel Chevrolet Lumina \\
\hline Type & 6 cylinder, 2 valves per cylinder, 4-stroke, spark-ignition \\
\hline Displacement & $3.1 \mathrm{~L}\left(192 \mathrm{in}^{3}\right)$ \\
\hline Bore & $89 \mathrm{~mm}(3.503 \mathrm{in})$. \\
\hline Stroke & $84 \mathrm{~mm}(3.312$ in.) \\
\hline Compression Ratio & $8.8: 1$ \\
\hline Useable Fuels & gasoline, methanol, ethanol, various gasoline-alcohol blends \\
\hline Fuel Metering & multi-port fuel injection \\
\hline
\end{tabular}

\subsubsection{Environmental Test Chamber}

An environmental test chamber was built to house the engine and to simulate cold ambient conditions. Test chamber specifications appear in Table 7-2. The test chamber is an aluminum-framed box with rigid foam insulation on all six sides. The chamber volume was sized so the combustion air during the engine start experiment was drawn directly from the chamber without an appreciable change in ambient air temperature. Once the thermal loads were estimated, the equipment was sized for $\mathrm{a}-40^{\circ} \mathrm{C}$ design point. Commercially available low-temperature refrigeration equipment was used for the cooling system. Practical limitations from time to time prevent the environmental test chamber from operating below $-20^{\circ} \mathrm{C}$. 
Table 7-2: Environmental Test Chamber Specifications

\begin{tabular}{|l|l|}
\hline Approximate dimensions & $1.5 \mathrm{~m} \times 1.8 \mathrm{~m} \times 1.6 \mathrm{~m}$ \\
\hline Interior volume & $4300 \mathrm{~L}$ \\
\hline Wall material & 2 -in. rigid foam insulation (R value of 14) \\
\hline Frame material & 2 in. $\times 2$ in. 6063 aluminum angle \\
\hline
\end{tabular}

\subsubsection{Data Acquisition System}

A DAC system was used to monitor the following engine, POX system, and emissions signals:

- Engine: speed (rpm), intake manifold pressure, ambient temperature, coolant temperature, exhaust temperature, battery voltage, key position (off/on/start), idle air control valve, and port fuel injectors (on/off)

- POX System: igniter (on/off), fuel injector pulse width, chamber temperature, heat exchanger exit temperature, and heat exchanger coolant temperature (in/out)

- Emissions: $\mathrm{HC}$ (in $\mathrm{C}_{3}$ ), $\mathrm{NO}_{\mathrm{x}}, \mathrm{CO}, \mathrm{CO}_{2}$, and $\mathrm{O}_{2}$.

All measurements were made on line. Emissions were not regularly measured, only once a satisfactory POX fueling rate was established.

\subsection{Testing Procedures}

To ensure that the tests were conducted in a repeatable manner, an experimental procedure was developed. Before each test the battery was fully charged to guarantee that each start had the same level of available energy. Furthermore, the engine was required to soak at the set-point temperature. In practice, this was typically an hour or more because of the time it took to achieve temperature uniformity $\left( \pm 1^{\circ} \mathrm{C}\right)$ with the test chamber ambient, engine coolant, engine exhaust, and POX chamber temperatures. Many seconds before cranking, the DAC system would begin collecting the engine, POX system, and emissions data. A test did not begin until the operator started cranking the engine. A cranking engine is characterized by having speeds around 100 and $200 \mathrm{rpm}$. The data were not always normalized to make the beginning of cranking equivalent to zero time. A test was completed once the engine started or when it failed to start after 30 seconds of cranking.

The best characterization of time to start was determined to be the first inflection point of the intake manifold pressure signal. This generally occurred when the engine speed was between 400 and $500 \mathrm{rpm}$ and the engine was clearly transitioning from cranking to running. 